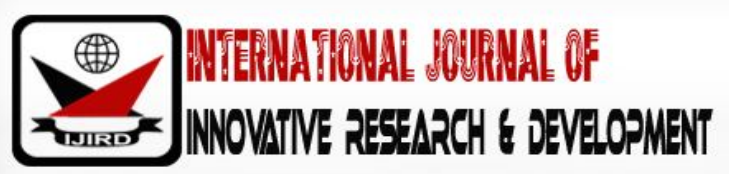

ISSN 2278 - 0211 (Online)

\section{Determinants of Profitability of Listed Deposit Money Banks in Anglophone Countries of West Africa (ACWA): A Cross Country Study}

Saheed Adekunle, Muraina

Assistant Chief Accountant (Audit), Pension Transitional Arrangement Directorate-PTAD, Nigeria

\begin{abstract}
:
This study investigates determinants of profitability of Deposit Money Banks in the Anglophone Countries of West Africa (ACWA) for the period of 2008-2015 using panel data of 21 listed banks drawn from two countries in Anglophone countries of West Africa with major stock exchanges. The independent variables were proxied by Capital Adequacy, Credit Risk, Bank Size and Inflation while profitability was proxied by Return on Assets (ROA. The study adopts correlational research design to examine the determinants of profitability of the Deposit Money Banks. The study found that both internal factors as well as macroeconomic factors had positively and strongly impacted on the deposit money banks' profitability over the study period. Capital adequacy and bank size have positive and significant relationships with bank profitability. The credit risk has a negative and significant relationship with bank profitability while inflation has a positive and insignificant relationship with bank profitability during the study period. It is therefore recommended among others that the Central Banks should effectively regulate the capital and the resources owned by the Deposit Money Banks (DMBs) in the sub-region by ensuring that a certain level of capital is kept with the Apex Banks for DMBs' financial soundness and stability. This will enable them continue to absorb losses and manage risk exposure.
\end{abstract}

Keywords: Deposit money banks, profitability, capital adequacy, credit risk, bank size, inflation

\section{Background to the Study}

The banking sector of Anglophone Countries of West Africa (ACWA) has gone through tremendous changes in the past few years and this has made it more competitive and largely contributive to economic stability and development as a result of their huge investment in information technology and automation such as Automated Teller Machine (ATM), Mobile Banking, Point of Sale (POS) as well as Internet Banking. The financial system therefore, stands as a vital ingredient in any economic environment of a Nation (Fentaw, 2015).

Commercial Banks, otherwise called, Deposit Money Banks serve as the bedrock and key players of the economy of nations and as such their relevance in the rapid development of economies cannot be overstressed. The financial sector performs an essential function in the development process of a country through financial intermediation (Chris, 2010). Proper functioning of Deposit Money Banks is required to facilitate the reliable provision and efficient management of scarce financial resources for promoting socio-economic developments.

Banking sector plays a crucial part in the economic growth of any nation and it also performs financial intermediation with the lowest possible cost with a view to achieving greater social welfare (Joaquín, 2004). The lower the cost of banking operations, the lower the social cost of financial intermediation and subsequently the higher, the bank profitability. Banks liquidation usually brings about systemic economic crisis. Hence, it is so vital to study determinants of Bank's profitability (Owoputi, Kayode and Adeyefa, 2014). This study will therefore dwell on factors such as capital adequacy, credit risk, bank size and inflation as they affect banks' profitability in Anglophone Countries of West Africa. The variables used in this study are described hereunder, together with the motivation for including them in the research work.

Capital adequacy usually serves as a safety net in case of any eventuality. High ratio of capital adequacy implies lower external financing and subsequently, higher profitability. Capital adequacy enables the banks to retain capital, absorb loan losses, support future growth of assets and provide return to investors (Qin and Pastory, 2012). Capital adequacy stands as banks' internal strengths to bear up losses in case of distress. When the ratio of capital adequacy is high, it is expected that the requirement for external finance will reduce, thereby leading to higher bank profitability (Johannes, 2015). The equity to total assets ratio as a measure of capital adequacy enables banks to absorb shocks that could lead to bank failures and losses. Highly capitalized banks are found to be more profitable than lowly capitalized ones because they incur less bankruptcy costs and less requirement for external financing particularly in developing economies (Almazari, 2013). The ability of banks to 
generate higher returns is a function of their levels of prudency in managing assets, liabilities and liquidity needs. It is envisaged that capital adequacy will have a positive effect on bank profitability because well-capitalized banks have lesser worries about insolvency.

Credit risk, which is proxied by loan loss provision ratio is relevant for determining bank profitability. That is why, the cross-country deposit money banks should be better prepared for the shock by having higher provision or reserve for likely loan defaults. This is because, the higher the value of the provision for loan losses, the lower the impact of the shock from uncollectible loans or credits because bad loans tend to reduce bank profitability. However, greater loan losses result in lower cash flows from principal and interest collections (Myrna, 2013). Banks should therefore gather satisfactory information during loan documentation from borrowers and even from third parties such as Credit Rating Agencies to mitigate the possibility of giving loans to potential loan defaulters. There is a need for banks to constantly review their credit control policies in line with the current industry norms, prevailing economic conditions in their respective countries. For this reason, in reducing banks' credit risk, their policies should set the rules on who should obtain credit, when and why one should access the credit as well as repayment arrangements and required collaterals (Angela, 2010). The coefficient of this variable is expected to be negative.

As banks grow in size, there is a tendency for economies of scale due to diminishing marginal returns. If a bank size increases by one unit, it is believed that it will generate a percentage increase in return on assets (ROA), thereby giving rise to increase in bank profitability as a result of increase in the number of bank branches and size of their investments. It was however, argued that the lower the size of a bank, the greater its profitability because large banks are faced with difficulty of investing their high liquidity, when compared to small banks. Huge initial costs of setting up large banks such as high technological costs, costs of research and developments and high political costs are associated with decrease in the profitability of large banks (Mohammad, 2015). In essence, what influences long-run profitability is not confined to size only because profitability is also a function of characteristics of individual banks and the markets where they function (Kristen and Rajdeep, 2016). On the other hand, Small banks may relate better with local customers and their business enterprises. The easy and advantageous access to small banks may neutralize the impact of diseconomies of scale. So, profitability needs to be measured in terms of costs and benefits associated with bank size in the environment in which the banking business operates.

In an anticipated inflation, banks are expected to factor the impact of future reduction in the value of money into their operational activities such that, as it occurs, they will be able to easily absorb the shock. The difference between actual or realized inflation and anticipated inflation is referred to as unanticipated inflation (Santoni, 1986). High inflation impacts negatively on deposit growth for the banking sector, thereby worsening the liquidity position in the system. It has been extensively evidenced that likely predictable high inflation rate can negatively affect long-run real growth of an economy (John, Ross and Bruce, 2000). This is because high inflation jeopardizes the value of money. Even anticipated rise in the rate of inflation impedes the financial sector's capacity to appropriately allocate resources (Naser and Abdollah, 2015). In reducing the impact of inflation on bank profitability, the central banks of countries under study need to ensure that the inflation rate is kept low and stable in terms of setting appropriate interest rates, open market operations, banking reserve requirements among others in order to guarantee safety and soundness of business activities including banking business enterprises in the sub-region. The coefficient of this variable is expected to be either negative or positive.

Profitability occurs when the income earned during a particular period of time is higher than the expenses incurred (Samuel, 2015). Banks, just like any other business ventures, generate profit when they can earn more money than expenses incurred. This bank profit comes largely from the fees charged for the services provided and the interest earned on a bank's assets while expenses are mainly incurred from the interest sustained on its liabilities. Banks' major assets include loans to individuals, corporate organizations and business enterprises as well as securities held as assets, whereas their liabilities are mainly the deposits and borrowings. The amount of profit to be generated depends on the banks' fees received on the services rendered and their net interest income earned is used to ascertain their return on assets (ROA), which represents bank profitability. Although, Rivard and Thomas (1997) contended that the best measure of bank profitability is through ROA since it is not distorted by high equity multiplier. It was conversely, argued that financial leverage is highly used by most banks to reasonably boost their Return on Equity (ROE) because ROA was found to be generating lower returns for the financial institutions (William, 2012). Use of banks' liabilities rather their capital to carry out investment opportunities enhance banks return on investments. Use of debts (financial leverage) to earn more money should however be done with caution in order not to precipitate credit crisis as witnessed in 2007 to 2009 Global Financial crisis. Hence, the need to manage risks associated with leverage.

There are several studies, \{ffuero and Michael (2014), Ayanda, Christopher and Mudashiru (2013), Aminu, (2013), Kanwal (2013), Kalluci (2011), Mathuva (2009) among others \} which showed that both bank -specific and macroeconomic determinants affect Deposit Money Banks' profitability. Both bank-level and macroeconomic factors such as capital adequacy, credit risk, bank size and inflation will be used in this study to determine the profitability of Deposit Money Banks in Anglophone Countries of West Africa over the period under study.

This paper is principally motivated by the fact that it will serve as a policy guide in the Sub-Saharan Banking Industry because there is no adequate and exhaustive information available for policy makers on banks' performance in the Sub-region that would be used as guidance in the Sub-Region's Banking sector. The findings of this study will significantly add to the body 
of knowledge regulating finance decisions in the countries under study. It will also contribute to the controversial academic debates concerning which internal and external variables influence banks' profitability.

\subsection{Statement of the Problem}

The banking system in Anglophone Countries of West Africa has witnessed series of issues and challenges ranging from banking consolidations, global financial crisis in 2007/ 08, bank recapitalization in 2011, particularly in Nigeria and of recent, ever changing Anglophone Countries of West African government policies, which have direct impact on the financial performance of banks in the sub-region.

The new and existing internal and external variables, which influence the profitability levels of the Deposit Money Banks, have brought a poser to bank executives within the Sub-region. What are the key variables affecting Deposit Money Banks' profitability in the Anglophone Countries of West Africa?

In determining factors affecting bank profitability, use of a single country data lowers the generalizability and opportunity of making comparison with other parts of the world (Asikhia, 2013). As recommended for further research by (Ani, Ugwunta, Ezeudu and Ugwuanyi, 2012), additional variables such as credit risk, and inflation will be included in determining bank profitability in the Sub-Region.

In view of the foregoing, the research will focus on Anglophone Countries of West Africa as developing Economies namely Gambia, Sierra Leone, Liberia, Ghana and Nigeria because most researches of this kind are carried out in advanced economies and few, if at all, in developing countries. As suggested by (Stephen, Kolapo and Aluko, 2014) a wider coverage needs to be considered by increasing the number of banks in the sample and the span of the study on the determinants of bank profitability. This study intends to duly cover the gap in the literature by widening the scope to the coverage of twenty-one (21) listed banks on active Stock Exchanges in Anglophone Countries of West Africa. Besides, to the best of the researcher's knowledge, there is no known previous empirical study on determinants of Bank profitability in Anglophone Countries of West Africa that has specifically related its research to the performance of listed deposit money banks in the sub-region.

Moreover, Nigerian authors such as (Ayanda, Christopher and Mudasiru, 2013), obtained a negative and significant relationship of capital adequacy with bank profitability; Isaac, Samuel and Hassan (2014) and (Stephen, Kolapo and Aluko, 2014) reported a positive but insignificant relationship between capital adequacy and bank's profitability; (Ejoh and Iwara, 2014) found the association between capital adequacy and bank profitability to positive and significant while Ghanaian Researchers such as Lawrence (2011), Ishmael (2015), obtained a positive and significant relationship between capital adequacy and bank's profitability. Not only that, Kolapo, Ayeni and Oke, (2012) found a negative and significant relationship between credit risk and bank profitability in Nigeria while Ishmael (2015) reported a positive association between credit risk and bank profitability in Ghana. Aburime (2008) also revealed that bank size has no significant relationship with bank profitability in Nigeria while Lawrence (2011), Ishmael (2015) reported a positively significant association between bank size and profitability in Ghana. The mixed findings observed in the previous studies have made the area of determinants of bank profitability still open for further research. Likewise, inconsistencies in a single-country study reports such as above inspired the researcher to undertake a cross-country study in Anglophone Countries in West Africa using the countries with active stock exchanges in the sub-region. Therefore, this study attempts to fill all these literature gaps identified.

\subsection{Objectives of the Study}

The main objective of the study is to investigate the impact of determinants of profitability of listed Deposit Money Banks in Anglophone Countries of West Africa. Specifically, the study is to:

- Examine the impact of capital adequacy on profitability of Deposit Money Banks in Anglophone Countries of West Africa.

- Identify the impact of credit risk on profitability of Deposit Money Banks in Anglophone Countries of West Africa.

- Evaluate the impact of bank size on profitability of Deposit Money Banks in Anglophone Countries of West Africa.

- Examine the impact of inflation on profitability of Deposit Money Banks in Anglophone Countries of West Africa.

\subsection{Hypotheses of the Study}

In line with the objectives of the study, the following hypotheses have been formulated in null forms.

- $\mathrm{H}_{0} 1$. Capital adequacy has no significant impact on profitability of Deposit Money Banks in Anglophone Countries of West Africa.

- $\mathrm{H}_{0} 2$. Credit risk has no significant impact on profitability of Deposit Money Banks in Anglophone Countries of West Africa.

- $\mathrm{H}_{0} 3$. Bank size has no significant impact on profitability of Deposit Money Banks in Anglophone Countries of West Africa.

- $\mathrm{H}_{0} 4$. Inflation has no significant impact on profitability of Deposit Money Banks in Anglophone Countries of West Africa. 


\subsection{Scope of the Study}

The study would examine the impact of determinants of profitability of listed Deposit Money Banks in Anglophone Countries of West Africa for the period of 2008 to 2015. The independent variables of the study are capital adequacy, credit risk, bank size and inflation while the dependent variable of the study was proxied by return on assets. The Deposit Money Banks were chosen as a domain of the study because of their strategic importance to Anglophone Countries of West African economy in terms of providing financial services for growth and development in Anglophone Countries of West Africa. The period of the study was selected because it covered the period of adoption of International Financial Reporting Standards (IFRS) in Anglophone Countries of West Africa.

\subsection{Significance of the Study}

The studies that concentrate on the financial sector of Anglophone Countries of West Africa are very few or if at all, in existence. Broad review of the literature indicates that there is a major gap in Anglophone Countries of West Africa on banking literature. Based on the best knowledge of the researcher, there is no one study conducted that exactly examines the determinants of Deposit Money Banks' Profitability conclusively in Anglophone Countries of West Africa.

However, if there are some papers on that, they cannot be the same due to the period, data, factors and methodology used, and their conclusions also may not be the same. The study concentrates on the internal and external performance indicators (determinants) such as Capital Adequacy, Credit Risk, Bank Size and Inflation.

Studies on bank performance in Anglophone Countries of West mainly used unquoted banks' Annual Reports, which make information value of such empirical studies highly disputable. Hence, the need to carry out this research, whose focus is on determining the profitability of listed deposit money banks in Anglophone Countries of West Africa as a contribution to the body of knowledge in these developing economies.

This study will also present more extensive and up-to-date evidences that are crucial for researchers, practitioners, and policy makers' management decisions.

In order to achieve the objective of the study, this paper is organized into five sections. The first section serves as an introduction. The second section is used for the review of relevant literatures. The third section handles the methodology of the research work. The fourth section is used for presenting and discussing the data result. The fifth section concludes the study by stressing more on the findings and the policy implications of the research work.

\section{Literature Review}

\subsection{Introduction}

There have been external shocks such as poor commodity prices and dwindling borrowing conditions and domestic constraints such as political and exchange rate instabilities, power shortages and internal conflict causing the fall of economic activities in Anglophone Countries of West Africa in recent times. For instance, there occurred a steep decline in economic activities of Anglophone Countries of West Africa from 4.6 percent in 2014 to 3.4percent in 2015, which was last experienced in 2009 financial crisis period (Gerard, 2016).

The Global financial crisis is still adversely affecting African economies as a result of a contraction in global trade, poor demand for African commodity exports, tighter foreign financing conditions and a fall in foreign direct investment (Alexis, 2009). The bank intermediations in Anglophone Countries of West Africa that could have cushioned the impact of the external shocks and internal constraints are still far from the category of developed markets. Because of this, the contribution of Anglophone Countries of West African banks to the sub-region growth and poverty reduction is still on low side.

The fundamental hypothesis of this study is mainly to investigate the determinants of the Deposit Money Banks' Profitability in Anglophone Countries of West Africa. The research works on the internal and external variables and their impacts on financial performance of banks are many. This study will only select those that could serve as a guide to the model specification of this empirical work. The literature review will help to show-case related studies to the variables used in this research. The researcher will therefore dwell on the variables vis: Capital Adequacy, Credit Risk, Bank Size, and Inflation in relation to the profitability or performance of Deposit Money Banks in Anglophone Countries of West. This section will specifically carry out a review of empirical studies, theoretical as well as conceptual framework on determinants of profitability of listed Deposit Money Banks in Anglophone Countries of West Africa.

\subsection{Conceptual Framework}

The major rationale behind the establishment of business enterprises is the profitability. Just like others, banks are the business organizations that continue to exist based on profit making. Bank profitability is a pointer to the efficiency of their management and therefore, serves as an easy allurement to attract investors. Profitability is usually measured by the return on assets (ROA) as employed by Molyneux and Thornton (1992); Athanasoglou, Brissimis and Delis (2005) and expressed as a function of firm-level and macroeconomic factors. 


\subsubsection{Capital Adequacy (EQTA)}

Capital adequacy is the amount of capital required for a bank as stipulated by the regulatory and supervisory authorities in order to achieve the banks financial health and soundness (Ejoh and Iwara, 2014). Capital Adequacy is also one of the factors endogenous to the bank profitability. This is computed by dividing equity to total assets. It shows the extent at which bank assets are by financed owners' equity. It is necessary for the financial regulators of commercial banks to maintain a minimum capital adequacy ratio to allow banks hold adequate level of equity to withstand any shocks that could occur (Mustafa and Bassam, 2012).

In 1988, Accord of Basel 1 laid down the criteria for determining the optimal size of a bank's capital. The minimum level of capital to be possessed by a bank was also established. Basel I has been able to define minimum capital of banks in terms of risks and solvability. Under Basel 1 rules, banks need to have capital rank in relation to weighted assets of $4 \%$ and the second rank of $8 \%$ respectively. Although, most banks in advanced countries currently have capital adequacy index of at least $10 \%$, the developing nations, especially in West Africa have not beefed up their capital adequacy to that level. In 2004, the provisions of Basel 1 were improved due to the complexity of risk involved in financial markets. Although the Basel 11 version still maintained the capital and minimum requirement of $8 \%$ of risk exposure, risk assessment methods were improved (Ellen and Song, 2014).

As concluded in the studies of Abreu and Mendes (2001), Kosmidou (2008), it is expected that capital adequacy will have a positive effect and significance on bank profitability because well-capitalized banks have lesser worries about insolvency (Hassan and Bashir, 2003). In accordance with advanced studies on bank profitability, well-capitalized banks experience negative returns (Almazari, 2013).

\subsubsection{Credit Risk (LLPTL)}

A loan loss provision is an amount, which is set aside for uncollected loans or credits. It is calculated as loan loss provision to total loans. The level of loan loss provision to total loans makes the bank managers to know their expectation about bank's asset quality. The higher the ratio, the lower the asset quality and vice versa. Conversely, the findings of Million, Matewos and Sujata (2015) defied the just-mentioned assertion and then reported there is a positive and significant relationship between credit risk and profitability.

The loan loss provision is depicted to be backward-looking and therefore, low ahead of banking crises. When crisis becomes imminent, it rapidly goes up as accumulated losses. The last banking crisis has made national and international authorities to start taking measures on promoting more forward-looking provioning practices that would lead to higher levels of bank reserves that absorb loan losses (Sarawan, Jason and Frank, 2009).

Basel III (or the Third Basel Accord) is a global, voluntary regulatory standard on bank capital adequacy, stress testing and market liquidity risk proposed by the Basel Committee on Banking Supervision to be implemented from 2019 in order to respond to the lapses in financial regulation, which led to the recent financial crisis. Basel III was formulated to improve capital requirements of banks as a way of enhancing their liquidity and leverage (Tesu Ramona, 2013).

When giving out loans, banks do bear it mind that borrowers would default, thereby not able to fully pay up the loan. When it shows that the borrowers may not redeem their loans, a bank will set aside a 'provision' to be charged to the income statement, which then appears on the face of the statement of financial position as a loan loss reserve. When a customer defaults eventually, the loan balance would then be reduced by making a charge to the loan loss reserve.

Although 2008 global financial crisis has made banks in Anglophone Countries of West Africa to enhance their standards for lending, they still experience delayed payment of loans and defaulted loan. The coefficient of this variable is anticipated to be negative in line with findings of Ahmed, Riaz and Muhammad, (2012), Fan (2014), Ishmael (2015), Manel (2015) for a conventional banking but contrary to the findings of Nor (2007), Boahene, Dasah and Agyei, (2012), Benson, (2015).

\subsubsection{Bank Size (Size)}

This ratio is calculated through the natural log of total assets. Large banks enjoy economies of scale, better diversification and comparative advantage in market-based bank activities. They are, however, riskier than small banks (Luc, Lev and Hui, 2014). The size of a bank enables it to have easy access to equity capital market, investing opportunities, portfolio diversification and reputation, leading to a lower capital ratio than smaller banks (Raman, Hamid and Khan, 2015). If a bank size increases by one unit, it will generate a percentage increase in return on assets (ROA), thereby giving rise to increase in bank profitability (Olorunfemi, 2016) but investment in and application of new technology enhances bank profitability than widening its size (Berger and Humphrey, 1997).

Banking systems in larger countries are more fragmented with strong savings and cooperative banking sectors whereas banking systems in smaller countries tend to be more concentrated (European Central Bank, 2014). Large banks are likely to have lower capital, less-stable funding, more market-based activities, and more organizationally complex than small banks, which could result in large banks having a distinct, riskier and likely more fragile business model and more systemic risk (Luc, Lev and Hui, 2014). Therefore, failures of such large banks are likely to negatively affect national and possibly international financial systems when compared to small banks' failures. Besides, if large banks fail, it has consequential effects on taxpayers as well as a national economy. 
Therefore, the Basel Committee on Banking Supervision has come up with a number of indicators to ascertain whether a bank is big enough to be a "global systemically important bank", or G-SIB. After G-SIB is determined, the committee would still go further to carry out additional supervisory requirements with a view to mitigating risk in the financial system. In line with the findings of Ahmed, Riaz and Muhammad, (2012), Mburu (2013), Francis (2013), Rahman, Hamid and Khan, (2015), Ibrahim (2016), the coefficient of this variable on bank profitability in Anglophone Countries of West Africa is expected to be positive because of economies of scale experienced within the sub-region during the study period. This is contrary to the results of Almazari (2013), Almazari (2014), AlGhusin (2015), Al-Mutairi (2015),

2.2.4 Inflation (INF): Inflation is a situation where there is a persistent rise in the general level of prices or a decline in the value of money over a period (Mohammed, Danjuma and Mohammad, 2014). Inflation is a rise in the general price level, usually expressed as an annual percentage rate of change (Santoni, 1986). In other words, inflation is the pervasive and continuous rise in the aggregate level of prices measured by an index of the cost of various goods and services, occasioned by wars, religious unrest, political instability, poor harvests, environmental upheavals kidnapping and other social malaise (Oleka, Eyisi and Ebue, 2015).

Inflation is one of the macroeconomic variables that affects bank profitability through changes in the general price level within an economy. It is estimated using annual inflation rate of a country at a particular point in time. Persistent inflation promotes capital flight, discourages capital inflow and domestic savings due to a fall in the value of money. During inflation, banks which are creditors will become born losers because their paper assets that were much more than their liabilities before tend to depreciate with inflation. Their capital equally depreciates with these paper assets during the inflationary period (Henry, 1980). The coefficient of this variable is expected to be either negative or positive. Duraj (2015), Naser (2015), Rahman, Hamid and Khan, (2015) found inflation coefficient to be negative in their study while the results of Molyneux and Thorton (1992), Idries, Khalifeh and Salaheddin (2010), Oleka, Eyisi and Onyeze (2014) revealed positive impact.

\subsection{Concept and Measurement of Profitability}

Bank profitability is a measure of bank performance. It was proxied by Return on Asset (ROA) in this study. ROA is an essential indicator normally employed in determining the performance of Deposit Money Banks particularly. Return on Assets (ROA) is an essential indicator of bank profitability. The higher this ratio the better profitability of banks (Herry, 2015). It is computed through dividing Profit after tax by total assets. ROA shows how banks are able to generate income from their assets. ROA may notwithstanding, be biased because of off-balance sheet activities. Samuel (2015). However, the principally used variable for determining bank performance is the Return on Assets (ROA) because it is not misrepresented by high equity multipliers. ROA is therefore a common indicator of bank profitability (Deger and Adem, 2011). ROA will be used extensively in the analysis of the research result in this research work.

\subsection{Empirical Review}

There exist many schools of thought on the impact of determinants of bank profitability and the influence of such on the microeconomic and macroeconomic indices of a country. Some studies on determinants of bank profitability concentrate on a single country while some others focus on cross-country studies. In this sub-section, studies on both single-country and cross-country on bank profitability were presented hereunder so as to make this research work more encompassing.

\subsubsection{Capital Adequacy and Bank Profitability}

Capital is an essential variable in determining bank profitability or financial performance. Capital adequacy is the amount of capital that is essential for a bank as determined by the regulatory and supervisory authorities to assume the banks financial health and soundness (Ejoh and Iwara, 2014). (Isaac, Samuel and Hassan, 2014) reported a positive and insignificant relationship between capital adequacy and bank's profitability. Secondary data of 14 listed deposit money banks in Nigeria from 2005 to 2012 was used. In the study, correlation research design was employed and in order to examine the relationship between profitability (dependent variable) and bank-specific factors (independent variables), ordinary least square (OLS) regression model was conducted. However, the study failed to test for Fixed Effect and Random Effect estimates, associated with panel data regression. Therefore, Ordinary Least Squares (OLS) estimate could lead to biased results (Christos and Geoffrey, 2011) about determinants of bank profitability.

In determining the relationship between profitability and capital adequacy of licensed Commercial Banks in Kenya from 2004 to 2009, (Chris, 2010) used a regression model to establish whether there is a significant relationship between dependent (ROA) and independent variable (Capital Adequacy). He then found a significant negative relationship between capital and ROA. He also remarked that capital is not the most significant determinant of ROA over the study period. Notwithstanding, the study was conducted in a single country, the result of which may not be used for generalization in a region such as ACWA.

Other studies that reported a positive relationship between capital adequacy and profitability are (Berger, 1995), (Hassan and Bashir, 2005), (Athanasoglou, Brissimis and Delis, 2005), (Sayilgan and Yildirim 2009), (Flamini, McDonald and Schumacher, 2009), (Davydenko, 2010), (Ani, Ugwunta, Ezeudu and Ugwuanyi, 2012), (Osborne, Fuertes and Alistair, 2013). (Ikpefan, 2013), (Ejoh and Iwara 2014), (Tuzcu, 2015), (Johannes, 2015), (Tamim, Haque and Alam, 2016). Other studies that 
found a negative relationship between capital and profitability include (Khalid, 2011), (Paolo, 2011), (Muhammad, 2011), (Xuezhi and Pastory 2012), (Almumani, 2013).

It is therefore hypothesized that capital adequacy will have a positive relationship with bank profitability and this is in line with the trade-off theory of capital structure, which states that in under-stressed conditions, banks may be able to improve their profitability by increasing capital ratios. It is also in consonance with Capital Adequacy Buffer Model (CABM), which helps to analyze the effect of Capital Adequacy on the dependent variable (ROA) proposed by (David, Michael, Robert and Abhay, 2013) and used by (Ikpefan, 2013).

\subsubsection{Credit Risk and Bank Profitability}

Credit Risk is represented by Loan Loss Provisions to Gross Loans. (Moody's, 2011) and it is used to amend loan loss reserves. Million, Matewos and Sujata (2015) empirically investigated the Impact of Credit Risk on Profitability Performance of eight selected Commercial Banks in Ethiopia using secondary data from the annual reports of the chosen banks for the years 2003-2004. Descriptive statistics and panel data regression were used to analyze the data. However, the results of the singlecountry study may not be used for generalization in a region such as ACWA.

The level of loan loss provision to total loans makes the bank managers to know their expectation about bank's asset quality. The higher the ratio, the lower the asset quality and vice versa. Conversely, the findings of Million, Matewos and Sujata (2015) defied the just-mentioned assertion and then reported there is a positive and significant relationship between credit risk and profitability. They recommended that improving credit management is required to maintain bank profitability.

Nonetheless, Noman, Pervin, Chowdhury and Banna (2015) examined the effect of credit risk on the profitability of the banking sectors of Bangladesh, using an unbalanced panel data and 172 observations from 18 private commercial banks from 2003 to 2013. They employed OLS, random effect model and GMM for analyzing the panel data. It was then reported that credit risk negatively influences the profitability of the commercial banks. They recommended that banks should apply prudent credit risk management procedure in order to enhance profitability. As however applied to Million, Matewos and Sujata (2015), the results of an investigation carried out on a single-country basis may not be used for generalization in a region such as ACWA.

It is therefore hypothesized that there is a negative and significant relationship between credit risk and bank profitability as reported by (Ahmed, Riaz and Muhammad, 2012),), (Kolapo, Ayeni and Oke, 2012), (Fan, 2014), (Ishmael, 2015), (Manel, 2015), Lucky and Nwosi (2015).

\subsubsection{Size and Bank Profitability}

The positive and significant coefficient of the bank size variable indicates the economies of scale. Market-power hypothesis and also the modern intermediation theory which posits that efficiency gains are associated with bank size because of economies of scale, on the condition that larger banks do not exist in very competitive environments. Whereas a negative coefficient of bank size implies that the association might be non-linear because of likely bureaucratic bottlenecks and managerial inefficiencies sustained by banks as they become "too large.", (Flamini, McDonald and Schumacher, 2009).

Although, the Efficient Structure Hypothesis (ESH) maintained that a positive relationship between concentration and profitability may indicate a positive relationship between size and efficiency, (Fentaw, 2015), this relationship can become negative if it is influenced by other variables. (Ahokpossi, 2013).

Aburime (2008) examined the determinants of bank profitability: company-level evidence from Nigeria by employing a panel data set consisting of 91 observations of 33 banks from 2000 to 2004. The regression results showed bank size does not significantly have a relationship with bank profitability, implying that large banks in the industry have not significantly enjoyed economies of scale. The single-country research was conducted prior to the era of 2005 bank consolidation and 2008 global financial crisis, which could have undermined its relevance in the present-day banking business due to various subsequent reforms on banks' minimum capital requirement, mergers and acquisitions among others that have emerged.

This study posits that size has a positive relationship with bank profitability, which is in line with the findings of (Ahmed, Riaz and Muhammad, 2012), (Mburu, 2013), (Francis, 2013), ((Raman, Hamid and Khan, 2015), (Ibrahim, 2016). Other studies that found a negative relationship between size and bank profitabiity include (Berger and Humphrey, 1997), (Fadzlan and Royfaizal, 2008), (Christos and Geoffrey, 2011)

\subsubsection{Inflation and Bank Profitability}

Inflation occurs when the cost of goods and services is more than the living standard of a country. Inflation demoralizes investors and also causes a negative effect on the market. (Muhammad and Naeem, 2015). This is due to the fact that a rise in anticipated inflation increases the nominal interest rate (Santoni, 1986).

One of the recent studies conducted was that of (Naser and Abdollah, 2015) in which the impact of Inflation on profitability of banks was examined from 2010 to 2013 using Generalized method of moments (GMM) to estimate the research model. Their result showed a strong correlation between inflation and banks' profitability. Nonetheless, the period of foursyears study may be inadequate enough to make any meaningful generalization about the findings.

Inflation may be negatively or positively related to profitability depending on whether it is anticipated or unanticipated (Perry, 1992). The position of the Positivists' theory is that inflation has a positive and significant effect on investment 
decision of organizations. Therefore, inflation is viewed to be encouraging investment and consequently giving rise to a more rapid economic growth through redistribution of income from wages to profits for the purpose of investment as argued by Griffiths (1979).

In line with this argument and since several studies such as (Flamini, McDonald and Schumacher 2009), (Anna and Hoi, 2009), (Naser and Abdollah, 2015) report a positive association between inflation and bank profitability, it is posited that the relationship between inflation and profitability will be positive in this study. Other studies such as (Anna and Hoi, 2009), found the relationship between inflation and bank profitability to be negative

Many theories have been presented in the literatures to establish the impact of bank-specific and macroeconomic determinants on banks' profitability. Those theories include Positivists' theory, which posits that inflation has a positive and significant effect on investment decision of organizations as stated by Griffiths (1979). Another one is the Efficient Structure Hypothesis (ESH), which maintained that a positive relationship between concentration and profitability may indicate a positive relationship between size and efficiency as put forth by (Fentaw, 2015). Also, the trade-off theory of capital structure states that in under-stressed conditions, banks may be able to improve their profitability by increasing capital ratios. It is also in consonance with Capital Adequacy Buffer Model (CABM), which helps to analyze the effect of Capital Adequacy on the dependent variable (ROA) proposed by (David, Michael, Robert and Abhay, 2013) and used by (Ikpefan, 2013).

\section{Research Methodology}

This study uses the correlational research design in order to investigate the impact of bank-specific and macroeconomic factors on bank profitability. The data were obtained from secondary sources only extracted from the audited annual reports and accounts of the banks. The population of the study contains the 23 Deposit Money Banks in the Anglophone countries of West Africa as at December, 2015 while the sample size is 21 with 168 observations. While obtaining the sample, banks that were quoted on the active stock exchanges in the Anglophone countries of West Africa for the time period 20082015 and whose data was available for the period of study were focused on. Banks that are not listed on active Stock Exchanges in Anglophone Countries of West Africa will not be considered. A Stock Exchange in Anglophone Countries of West Africa is considered inactive if it does not have at least two trading securities or firms listed on it and their annual financial reports consistently published periodically. Securities in these inactive markets, have relatively low trading volumes and may not even trade for a certain period in a year. (David, Michael, Robert and Abhay, 2003).

As at 31st December, 2015, the listed Deposit Money Banks on the Stock Exchange of Nigeria were fifteen (15) and that of Ghana were eight (8) respectively. Whereas, fourteen (14) and seven (7) Deposit Money Banks quoted on the Stock Exchange in Nigeria and Ghana between 2008-2015 study period were selected based on the availability of data.

The regression technique was also applied for the data analysis by using SPSS, stata and E-Views as appropriate. The variance inflation factor and tolerance values (VIF) was used to detect any existence of multicollinearity while necessary regression diagnostics tests were carried out for heteroskedasticity.

In order to determine the impact of bank-specific and macroeconomic variables on bank profitability in ACWA, a multiple linear model is established. The model summarizes the influence of Capital Adequacy, Credit risk, bank size and inflation on bank profitability. In this study, the bank-level and macroeconomic factors affecting the profitability of Deposit Money Banks in ACWA were assessed from the data collected and the values obtained were then substituted in the model of the study stated below in line with previous studies such as (Shehu and Abubakar, 2012), (Shehu and Musa, 2014), (Ahmad, 2014), (AlGhusin, 2015), (Olaoye, 2015) but adapted and modified to suit the best purpose of this research.

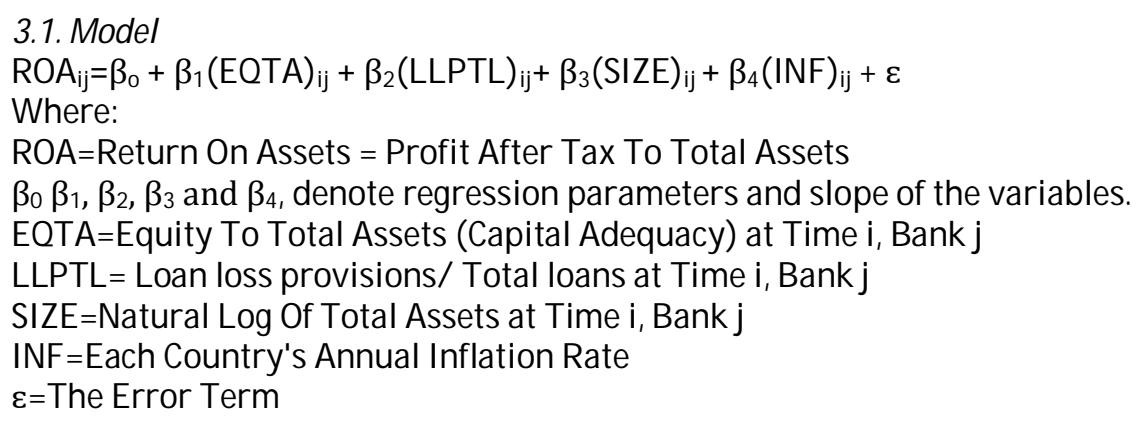

\section{Result and Discussions}

In this section, the result of data analysis and hypothesis testing will be presented. The outputs of descriptive statistics, correlation matrix table and subsequently the summary of regression will be discussed. Necessary policy implications of the findings and recommendation will be made. 


\begin{tabular}{|c|c|c|c|c|c|c|c|}
\hline Variables & OBS & Mean & Std Dev. & Mini. & Maxi. & Skewness & Kurtosis \\
\hline Return on Asset(ROA) & 167 & 0.01683 & 0.03876 & -0.3 & 0.1 & 0.00000 & 0.00000 \\
\hline Capital Adequacy (eqta) & 167 & 0.13988 & 0.06843 & -0.2 & 0.31 & 0.00000 & 0.00000 \\
\hline Credit Risk (llptl) & 167 & 0.04772 & 0.10755 & 0 & 1.08 & 0.00000 & 0.00000 \\
\hline Bank Size (size) & 167 & 8.15539 & 1.19504 & 5.23 & 10.2 & 0.00464 & 0.00120 \\
\hline Inflation (inf) & 168 & 11.7458 & 3.02356 & 8 & 19.2 & 0.00010 & 0.91620 \\
\hline
\end{tabular}

Table 1

Source: Strata Summary Statistic Result

From Table 1 above, the mean value for Return on Assets is 0.0168263 for the banks. The Capital Adequacy and Credit Risk have mean values of 0.1399 and 0.0477 respectively. Bank Size has an average value of 8.1554 while Inflation has a mean value of 11.746. The minimum value for the Return on Assets is minus 0.3 while the maximum is 0.1 implying that there is a greater management efficiency in using theirs to generate higher returns. Inflation recorded the highest standard deviation among the explanatory variables, which shows that it has the lowest contribution to the dependent variable (ROA).

\subsection{Multicollinearity}

Variance Inflation Factor (VIF) was estimated to detect any presence of multicollinearity. The VIF of the variables fell between 1 and 10 as shown in table 4.3.2 below, meaning that the variables suffer no multicolinearity because a statistical research model of tolerance coefficients that are not so close to zero, is deemed not to have a problem of multicollinearity (Gujarati, 1995). Low mean VIF of 1.23 was also obtained confirming the assertion that maximum VIF of 1.96 does not imply critical multicollinearity (Kennedy, 2008).

\begin{tabular}{|c|c|c|}
\hline Variable & VIF & 1/ VIF \\
\hline 11ptl & 1.26 & 0.790923 \\
eqta & 1.26 & 0.795295 \\
size & 1.20 & 0.835676 \\
inf & 1.19 & 837685 \\
\hline Mean VIF & 1.23 & \\
\hline \multicolumn{3}{|c}{ Table 2}
\end{tabular}

\subsection{Correlation Matrix}

The table below presents the correlation values between the dependent variable and the independent variables and also the relationship between the independent variables themselves. The values were obtained from the Pearson correlation of two-tailed significance.

\begin{tabular}{|c|c|c|c|c|c|}
\hline & ROA & EQTA & LLPTL & SIZE & INF \\
\hline ROA & 1.000 & & & & \\
\cline { 1 - 4 } EQTA & 0.437 & 1.000 & & & \\
\cline { 1 - 4 } LLPT & -0.67 & -0.451 & 1.000 & & \\
\hline SIZE & -0.095 & 0.006 & -0.072 & 1.000 & \\
\hline INF & 0.077 & 0.009 & 0.049 & -0.402 & 1.000 \\
\hline \multicolumn{7}{|c|}{ Table 3 } \\
Source: SPSS Output
\end{tabular}

From the Table above, the matrix shows that the relationship between the independent variables does not reveal any presence of the problem of multicollinearity. Multicollinearity occurs as a problem when the correlation is greater than 0.80 as stated by Kennedy (2008). All correlation coefficients below are less than 0.80 implying that the independent variable EQTA and INF had positive relationships with dependent variable (ROA) of listed deposit money banks in Anglophone countries of West Africa while LLPTL and SIZE had negative relationships with ROA of listed deposit money banks in Anglophone countries of West Africa. Three of the independent variables had negative associations while three among the independent variables had positive relationships. 


\subsection{Summary of Regression Result}

Table 3 below shows the regression result of the dependent variable (ROA) and the independent variables of the study (EQTA, LLPTL SIZE and INF). The analysis of the relationship and impact between the independent variables and the dependent variable used in this research work is presented hereunder together with the cumulative analysis.

\begin{tabular}{|c|c|c|c|c|c|c|}
\hline \multicolumn{7}{|c|}{ Fixed Effect GLS Regression } \\
\hline Panels: & \multicolumn{7}{|c|}{ Heteroskedasticity corrected with White Robust Std Error Test } \\
\hline Correlation & \multicolumn{2}{|c|}{ No Autocorrelation } & & & \\
\hline Variables & Coeff. & Robust Std Error & T-Test & P.Value & & \\
\hline Capital Adequacy (eqta) & 0.16055 & 0.065177 & 2.46 & $0.023^{* *}$ & \\
\hline Credit Risk (llptl) & -0.1928 & 0.032812 & -5.88 & $0.000^{* * *}$ & \\
\hline Bank Size (size) & 0.02309 & 0.006981 & 3.31 & $0.004^{* * *}$ & \\
\hline Inflation (inf) & 0.00131 & 0.000806 & 1.62 & 0.121 & & \\
\hline Constant & -0.2001 & 0.070791 & -2.83 & $0.010^{* * *}$ & \\
\hline No. of Obs. & 167 & & & & & \\
\hline Group Banks & 21 & & & & & \\
\hline R.sq: Within & 0.4758 & & & & & \\
\hline Between & 0.0257 & & & & & \\
\hline Overall & 0.1755 & & & & \\
\hline Prob > F $=$ & 0 & & & & & \\
\hline
\end{tabular}

Table 4: Summary of Regression Result

Source: Panel Estimation, 2008-2015 Using Stata

Note: 1. (Ln) implies natural logs;

2. $(* * ; * * ; *)=$ Significant at $1 \%, 5 \%$ and $10 \%$, respectively.

The table above encapsulates the regression result, implying that Credit Risk and Bank size are significant at 1\%, while Capital Adequacy is significant at $5 \%$. Inflation is not significant. The model is therefore estimated in the following way: $=-0.2+0.1605 \mathrm{EQTA}_{\mathrm{ij}}$ - 0.1928LLPTL $\mathrm{ij}+0.02309 \mathrm{SIZEij}+0.0013 \mathrm{INFij}+$

The result shows a negative relationship between credit risk and return on assets(ROA), while a positive and significant relationship occurs between capital adequacy and bank size.

As shown above, $47.58 \%$ of the deviation in the dependent variable is explained by independent variables. The remaining $52.42 \%$ is not explained by the independent variables above. This shows that the model of the study is fit and the independent variables are properly chosen, brought together and used.

As expected, the effect of capital adequacy represented by equity to total assets (eqta) showed a positive coefficient and significant at $5 \%$ on ROA, a measure of profitability. Basically, a 5\% change in equity fund obtained from shareholders leads to an increase in bank profitability by $16.05 \%$ while other factors are held constant. This implies that the banks under study can absorb losses and manage risk exposure with shareholders. This result is consistent with that of (Abreu and Mendes, 2001), (Kosmidou, 2008).

As anticipated, the coefficient of credit risk measured by loan loss provision to total loans(LLPTL) revealed a negative and statistically significant at 1\% level of significance on ROA of banks in Anglophone Countries of West Africa (ACWA). A 1\% increase in LLPTL will lead to a decrease in bank profitability by $19.28 \%$ while other variables remain constant. This result is consistent with findings of (Ahmed, Riaz and Muhammad, 2012), (Fan, 2014), (Ishmael, 2015), (Manel, 2015) and (Melaku, 2016). So, there is a need for the countries in Anglophone Countries of West Africa (ACWA) to establish and maintain a central database called Credit Risk Management System across banks in their domains, which would be generating accurate and reliable credit information on bank borrowers as a way of assessing the repayment capabilities of the customers to be granted credit facilities. This will definitely reduce the incidents of non-performing or abandoned loans in the banks under study.

The coefficient of natural logarithm of total assets (SIZE) variable, which represents Bank Size shows a positive and significant relationship with bank profitability at 1\% with expected signs. The positive coefficient of size implies that the ACWA banks were able to utilize their assets in accordance with economies of scale. A one dollar increase in investment in total assets yields a proportionate increase of banks' profitability by $23.09 \%$ dollar while other factors remain constant. Therefore, the positive and significant coefficient of bank size in this study is consistent with economies of scale Efficient Structure Hypothesis, which propounded that larger firms can sustain lower unit cost and higher returns by way of economies 
of scale. Our finding has the same bearing with that of (Ahmed, Riaz and Muhammad, 2012), (Mburu, 2013), (Francis, 2013), (Raman, Hamid and Khan, 2015), (Ibrahim, 2016), (Melaku, 2016).

The coefficient of inflation variable showed a positive and insignificant relationship with bank profitability. In line with the Economic theory on Inflation, the positive sign showed that the bank management were able to factor the impact of inflation anticipation in their cost structure, but the significance of a such forecast on bank profitability was found to be marginal. As shown by our finding, the results of (Molyneux and Thorton, 1992), Idries, Khalifeh and Salaheddin (2010) and Oleka, Eyisi and Onyeze (2014) also revealed a positive impact of inflation on bank profitability.

\section{5 .Test of Hypothesis}

This result produces an evidence of rejecting or not rejecting the null hypothesis.

- $\mathrm{H}_{0}$ a: Capital Adequacy has no significant impact on the Profitability of Deposit Money Banks in Anglophone Countries of West Africa.

Based on the above fixed effects estimations, there is a positive and significant relationship between capital adequacy and bank profitability $5 \%$ level of significance. Therefore, the null hypothesis is rejected as expected. This positive correlation between capital adequacy and bank profitability is consistent with previous studies of (Abreu and Mendes, 2001), (Kosmidou, 2008).

- $\mathrm{H}_{0}$ b: Credit Risk has no significant impact on the Profitability of Deposit Money Banks in Anglophone Countries of West Africa.

There was a negative and statistically significant relationship between credit risk and bank profitability as expected. Therefore, the null hypothesis is rejected. This is consistent with studies of (Ahmed, Riaz and Muhammad, 2012), (Fan, 2014), (Ishmael, 2015) and (Manel, 2015).

$\mathrm{H}_{0}$ c: Bank Size has no significant impact on the Profitability of Deposit Money Banks in Anglophone Countries of West Africa. The result showed that the impact of bank size on profitability was significant. So, the null hypothesis is rejected. This result is in line with that of (Ahmed, Riaz and Muhammad, 2012), (Mburu, 2013), (Francis, 2013), ((Raman, Hamid and Khan, 2015), (Ibrahim, 2016), (Melaku, 2016).

$\mathrm{H}_{0} \mathrm{~d}$ : Inflation has no significant impact on the Profitability of Deposit Money Banks in Anglophone Countries of West Africa. Inflation had no statistically significant relationship with bank profitability. So, the null hypothesis is accepted. This result is consistent with previous studies of (Molyneux and Thorton, 1992), Idries, Khalifeh and Salaheddin (2010) and Oleka, Eyisi and Onyeze (2014).

\begin{tabular}{|c|c|c|c|c|c|c|}
\hline Variables & Coeff. & Std. Error & T-Test & P. Value & $\begin{array}{c}\mathbf{H}_{\mathbf{0}} \\
\text { Not Rejected }\end{array}$ & $\begin{array}{c}\mathbf{H}_{\mathbf{0}} \\
\text { Rejected }\end{array}$ \\
\hline Capital Adequacy (eqta) & .1605456 & 0.065177 & 2.46 & $0.023^{* *}$ & & \\
\hline Credit Risk (llptl) & -.1928046 & 0.032812 & -5.88 & $0.000^{* * *}$ & & \\
\hline Bank Size (size) & .0230923 & 0.006981 & 3.31 & $0.004 * * *$ & & \\
\hline Inflation (inf) & .001305 & 0.000806 & 1.62 & 0.121 & & \\
\hline
\end{tabular}

Table 5: The Summary of Hypotheses Testing

Author's compilation

\subsection{Policy Implication of the Findings}

The policy implications obtained from this study point to the importance of bank-specific and macroeconomic determinants in enhancing profitability in Anglophone Countries of West Africa. This paper therefore serves as a guide for improving policies of ACWA's banking sector. The signs of the factors affecting banks' profitability in ACWA have crucial policy implications as described below:

- Based on our findings, capital adequacy is found to be significant, a positive sign of this variable could imply that banks in ACWA have the ability to retain capital, absorb loan losses, support future growth of assets and also generate returns to shareholders. In ensuring that this is sustainable, banking sector regulators in Anglophone Countries of West Africa (ACWA) should ensure that banks hold adequate amount of reserves to be able to absorb losses and also mitigate the effect of adverse shocks to the economies. On a periodic basis, the regulators should conduct efficient and effective monitoring and supervision of banks under their regimentation in terms of maintaining the minimum capital requirement for optimum utilization of resources and avoiding bank distress.

- The coefficient of loan loss provision to total loans, which is a proxy of credit risk showed a significant impact on bank profitability. The study also reported a negative sign. The implication of this sign is that the banks examined in this study had a high a variation vis-a-vis credit risk management. Therefore, a sound credit risk policy should be maintained by the banks for better profitability. The regulators of the banking industry in the respective countries in ACWA should also ensure that prudent credit risk management procedures are regularly followed. Besides, there is a 
need for the regulators to be watchful against excessive risk-taking that could threaten financial stability of the banks. The regulators should also promote policies that foster sound supervision of borrowers to avoid non-performing loans.

- Bank size was discovered to have had a significant influence on banks' profitability in the sub-region. The coefficient of the variable was also positive, indicating that it is consistent with structure-conduct-performance hypothesis, which could be as a result of some internal factors such as operational efficiencies and good credit risk management. A more effective regulatory policy that strengthens banks' expansions, competitive positions and more establishment of foreign financial institutions should continue to be upheld in the sub-region.

- Another macroeconomic factor, inflation was also discovered to be statistically insignificant. The coefficient of this variable was positively associated with bank profitability, which implies that the determinant was anticipated by the management of the banks during the study period by adjusting interest rates accordingly so as to reduce the cost of inflation. In order to cushion the effect of inflation, bank managers in ACWA can equally trade in bonds and other securities that are in line with their business models for higher returns.

\section{Conclusions and Recommendations}

The paper investigates the determinants of the profitability of Deposit Money Banks in the Anglophone countries of West Africa (ACWA). The capital adequacy, credit risk, bank size and inflation represent independent variables while dependent variable was proxy by Return on Assets (ROA). It was found that Capital Adequacy and Bank Size have a positive and significant impact on the Return on Assets (ROA) of listed deposit money banks in the Anglophone countries of West Africa, whereas Credit Risk has a negative and significant influence on the Return on Assets (ROA) of listed deposit money banks in the Anglophone countries of West Africa. Inflation has a positive and insignificant impact on the Return on Assets (ROA) of listed deposit money banks in the Anglophone countries of West Africa. Therefore, the result indicates that bankspecific variables have strongly and significantly influenced profitability of listed deposit money banks in the Anglophone countries of West Africa during the study period. Based on the findings, it is recommended that the Central Banks should effectively regulate the capital and the resources owned by the Deposit Money Banks (DMBs) in the sub-region by ensuring that a certain level of capital is kept with the Apex Banks for DMBs' financial soundness and stability. This will enable them to continue to absorb losses and manage risk exposure with shareholders.

It is also recommended that the Apex Banks (Central Bank of Nigeria and Central Bank of Ghana and others in Anglophone countries of West Africa) should establish and maintain a central database called Credit Risk Management System across banks in their domains, which would be generating accurate and reliable credit information on bank borrowers as a way of assessing the repayment capabilities of the customers to be granted credit facilities. With this in place, it is believed that the incidents of non-performing or abandoned loans in the banks under study will reduce to a barest minimum.

It is equally recommended that the Deposit Money Banks should improve their investments especially in the area of virtual banking for higher efficiency and profitability.

In line with the findings, the listed banks were able to factor the impact of inflation into their operations. The Apex Banks should, however, increase the reserve requirements of the banks under study so as to reduce inflation in the sub-region in the foreseeable future.

\section{References}

i. Abba Gabriel Ogere, Zachariah Peter and E.E Inyang (2013). Capital Adequacy Ratio and Banking Risks in the Nigeria Money Deposit Banks. Research Journals of Finance and Accounting. Vol.4, No.17.

ii. Abreu and Mendes, (2001). Commercial Bank Interest Margins and Profitability: Evidence for some EU countries.

iii. Abu Hanifa Noman, Sajeda Pervin, Mustafa Manir Chowdhury and Hasanul Banna (2015). The Effect of Credit Risk on the Banking Profitability: A Case on Bangladesh. Global Journal of Management and Business Research: C Finance. Volume 15 Issue 3 Version 1.0

iv. Agbeja, O., Adelakun O. J. and Olufemi F.I. (2015). Capital Adequacy Ratio and Bank Profitability in Nigeria: A Linear Approach. International Journal of Novel Research in Marketing Management and Economics Vol. 2, Issue 3, pp: (9199)

v. Ahmad Aref Almazari (2013). Capital Adequacy, Cost Income Ratio and the Performance of Saudi Banks (2007-2011). International Journal of Academic Research in Accounting, Finance and Management Sciences Vol. 3, No. 4

vi. Ahmed Raza ul Mustafa, Riaz Hussein Ansari and Muhammad Umair Youni (2012). Does the Loan Loss Provision Affect The Banking Profitability In Case Of Pakistan? Asian Economic and Financial Review 2(7)

vii. Akano Ajibola Isaac Kazeem Hammed Samuel and Shehu Usman Hassan (2014). Internal Attributes and Profitability of Listed Deposit Banks in Nigeria. KASU Journal of Accounting Research and Practice, Vol.3 Issue 1.

viii. Alexis Arieff (2009) The Global Economic Crisis: Impact on Sub-Saharan Africa and Global Policy Responses: Congressional Research Service 7-5700 www.crs.gov.

ix. Ani W. U., Ugwunta D. O., Ezeudu I.J. and Ugwuanyi, G. O. (2012): An empirical assessment of the determinants of bank profitability in Nigeria: Bank characteristics panel evidence: Journal of Accounting and Taxation Vol. 4(3).

x. Anna P. I. Vong and Hoi Si Chan, (2009).Determinants of Bank Profitability in Macao. 
xi. Antonina Davydenko (2010): Determinants of Bank Profitability in Ukraine-Undergraduate Economic Review-Volume 7,Issue 1, Article 2

xii. Asikhia Olalekan and Sokefun Adeyinka, (2013).Capital Adequacy And Banks' Profitability: An Empirical Evidence From Nigeria. American International Journal of Contemporary Research Vol. 3 No. 10

xiii. Athanasoglou, P., Brissimis, N. \& Delis, D. (2005). Bank-specific, industry specific and macroeconomic determinants of bank profitability, Journal of International Financial Markets, Institutions \& Money.

xiv. Ayșe Altıok Yılmaz (2013). Profitability of Banking System: Evidence from Emerging Markets. WEI International Academic Conference Proceedings Antalya, Turkey.

xv. Badi H. Baltagi(2005),Econometric Analysis of Panel Data: Third Edition.

xvi. bankprofitability in Croatia. Economic Research-Ekonomska Istraživanja

xvii. Berger, A. N. (1995). The relationship between capital and earnings in banking. Journal of Money Credit and Banking 27, 432-456.

xviii. Berger, A.N. and Humphrey, D.B. (1997). Efficiency of financial institutions: international survey and directions for future research. European Journal of Operational Research, Vol 98, pp.175-212.

xix. Calixte Ahokpossi (2013). Determinants of Bank Interest Margins in Sub-Saharan Africa. IMF Working Papers.

xx. Chioma Dorothy Oleka, Eyisi Adanma Sabina and M.I. Ebue (2015). Relationship Between Inflation and Firms' Performance-Evidence from Nigeria. World Applied Sciences Journal 33 (5).

xxi. Chris Maina Kiragu (2010). The Relationship Between Profitability and Capital Adequacy Of Commercial Banks In Kenya.

xxii. Christos K. Staikouras and Geoffrey E. Wood (2011). The Determinants Of European Bank Profitability. International Business \& Economics Research Journal Volume 3, Number 6.

xxiii. David, Michael, Robert and Abhay (2013). A Capital Adequacy Buffer Model.

xxiv. Economic Department.

xxv. Ellen Gaston and In Won Song (2014).Supervisory Roles in Loan Loss Provisioning in Countries Implementing IFRS. International Monetary Fund WP/ 14/ 170. IMF Working Paper.

xxvi. European Central Bank (2014). Banking Structures Report.

xxvii. European Central Bank(2010). Beyond ROE - How to Measure Bank performance. Appendix to the report on EU banking structures.

xxviii. Fadzlan Sufian and Royfaizal Razali Chong (2008). Determinants of Bank Profitability in a Developing Economy: Empirical Evidence from the Philippines. Asian Academy of Management Journal Of Accounting And Finance. AAMAF, Vol. 4, No. 2, 91-112.

xxix. Fan Li and Yijun Zou (2014). The Impact of Credit Risk Management on Profitability of Commercial Banks: A Study of Europe.

xxx. Fentaw Leykun Fisseha (2015). Meta Analysis on the Determinants of Commercial Bank's Profitability: (A Conceptual Frame Work And Modelling). European Scientific Journal vol.11, No.19

xxxi. G. J. Santoni (1986). The Effects of Inflation on Commercial Banks. Federal Reserve Bank of St. Louis.

xxxii. Griffiths, B. (1977). Inflation: The Price of Property, London: Weidenfield and Nicolson Limited. London.

xxxiii. Grygorenko, O. (2009). Effects of Price Setting on Bank Performance:The case of Ukraine, Kyiv

xxxiv. Gujarati D.N.(1995) Basic Econometrics, 3e.

xxxv. Hassan, M.K. and Bashir, A. H. (2005). Determinants of Islamic Banking Profitability. In Munawar Iqbal and Rodney Wilson (Eds.), Islamic Perspectives on Wealth Creation, Edinburgh: Edinburgh University Press.

xxxvi. Herry Achmad Buchory (2015). Banking Profitability: How does the Credit Risk and Operational Efficiency Effect?

xxxvii. Ibrahim Nandom Yakubu (2016). Bank-Specific and Macroeconomic Determinants of Commercial Banks Profitability in Ghana. International Finance and Banking Vol. 3, No. 2.

xxxviii. Idries M. Al-Jarrah, Khalifeh N. Ziadat and Salaheddin Y. El-Rimawi (2010). The Determinants of the Jordanian's Banks Profitability: A Cointegration Approach. Jordan Journal of Business Administration, Volume 6, No. 2.

xxxix. Ikpefan Ochei A.(2013), Capital adequacy, management and performance in the Nigerian Commercial bank (1986 2006). African Journal of Business Management, Vol. 7(30) in banking: Evidence from US banks.

xl. International Settlements(BIS) Working Papers No 238. Monetary and

xli. Ishmael A.G. and Benjamin Amoah (2015). Determinants of Bank Profitability in Ghana. International Journal of Accounting and Financial Reporting. Vol. 5, No. 1

xlii. Iwedi Marshal \& Onuegbu Onyekachi (2014)Credit Risk and Performance of Selected Deposit Money Banks in Nigeria: An Empirical Investigation. European Journal of Humanities and Social Sciences Vol. 31, No.1

xliii. James Ayodele Owoputi, Olawale Femi Kayode and Felix Ademola Adeyefa (2014). Bank Specific, Industry Specific and Macroeconomic Determinants of Bank Profitability in Nigeria. European Scientific Journal. vol.10, No.25.

xliv. Joaquín Maudos and Juan Fernández de Guevara (2004).Factors Explaining The Interest Margin In The Banking Sectors Of The European Union. 
xlv. Johannes D.M. Mathuva, (2009). Capital Adequacy, Cost Income Ratio and the Performance of Commercial Banks: The Kenyan Scenario. The International Journal of Applied Economics and Finance, 3: 35-47.Journal of Accounting and Financial Reporting. Vol. 5, No. 1

xlvi. Johannes Peyavali Sheefeni Sheefeni (2015). Examining the Bank Specific Determinants of

xlvii. John H. Boyd, Ross Levine and Bruce D. Smith (2000). The Impact of Inflation on Financial Sector Performance.

xlviii. Journal of Business and Management Sciences, Vol. 3, No. 4

xlix. Kennedy, Peter (2008). A Guide to Econometrics 6ed. Malden: Wiley-Blackwell.

1. Khalid Ashraf Chishty (2011). The Impact Of Capital Adequacy Requirements On Profitability Of Private Banks In India (A Case Study Of J\&K, Icici, Hdfc And Yes Bank). International Journal Of Research In Commerce \& Management. Volume No: 2, Issue No. 7.

li. Kolapo T. Funso, Ayeni R. Kolade and Oke M. Ojo (2012). Credit Risk and Commercial Banks' Performance in Nigeria: a Panel Model Approach. Australian Journal of Business and Management Research Vol.2 No.02

lii. Kristen Regehr and Rajdeep Sengupta (2016). Has the Relationship between Bank Size and Profitability Changed? Economic Review. Federal Reserve Bank of Kansas City

liii. Kyriaki Kosmidou (2008) The determinants of banks' profits in Greece during the period of EU financial integration. Managerial Finance Vol.34 No.3.

liv. Lawrence Kusienyo (2011). The Determinants of Profitability of Banks in Ghana. A Thesis submitted to the Institute of Distance Learning, Kwame Nkrumah University of Science and Technology in partial fulfilment of the requirements for the degree of Commonwealth Executive Masters Of Business Administration (CEMBA).

lv. Luc Laeven, Lev Ratnovski and Hui Tong (2014). Bank Size and Systemic Risk. International Monetary Fund. IMF Staff Discussion Note.

lvi. Lucky Anyike Lucky and Nwosi, Anele Andrew (2015).Asset Quality and Profitability of Commercial Banks: Evidence from Nigeria. Research Journal of Finance and Accounting Vol.6, No.18.

lvii. Maja Pervan, Iva Pelivan and Josip Arnerić (2015). Profit persistence and determinants of

lviii. Manel Hadriche (2015). Banks Performance Determinants: Comparative Analysis between Conventional and Islamic Banks from GCC Countries. International Journal of Economics and Finance; Vol. 7, No. 9.

lix. Matthew Osborne, Ana-Maria Fuertes and Alistair Milne (2013). Capital and profitability

lx. Mburu, Ruth Muthoni (2013). The effect of liquidity and solvency on the profitability of Commercial Banks in Kenya.

lxi. Melaku, Aweke Merin (2016). Determinants of Bank Profitability in Ethiopia:A Case Study of Private Commercial Banks. Research Journal of Finance and Accounting. Vol.7, No.7.

lxii. Million Gizaw, Matewos Kebede and Sujata, (2015). The Impact of Credit Risk on Profitability Performance of Commercial Banks in Ethiopia. African Journal of Business Management. Vol.9(2), pp.59-66.

lxiii. Mohammad Suleiman Aladwan (2015). The Impact of Bank Size on Profitability: An Empirical Study On Listed Jordanian Commercial Banks. European Scientific Journal vol.11, No.34

lxiv. Mohammad, Abdelkarim Almumani (2013). Impact of Managerial Factors on Commercial Bank Profitability: Empirical Evidence from Jordan. International Journal of Academic Research in Accounting , Finance and Management Sciences Vol. 3, No.3.

lxv. Mohammad, Morshedur Raman, Kowsar Hamid and Abdul Mannan Khan (2015). Determinants of Bank Profitability: Empirical Evidence from Bangladesh. International Journal of Business and Management; Vol. 10, No. 8.

lxvi. Mohammed Umar, Danjuma Maijama'a and Mohammad Adamu (2014). Conceptual exposition of the effect of inflation on bank performance. Journal of World Economic Research 3(5)

lxvii. Molyneux and Thorton (1992) come to a conclusion that there is a negative correlation between liquidity and profitability levels.

lxviii. Moody's Investor Service (2011) Banking Account \& Ratio Definitions Moody's Investors Service. available at:https:/ / www moodys.com/ sites/ products/ ProductAttachments/ Banking\%20Account\%20and\%20Ratio\%20Defin itions.pdf

lxix. Muhammad Farhan Akhtar(2011). Factors Influencing the Profitability of Conventional Banks of Pakistan. Euro Journals Publishing, Inc. Issue 66.

lxx. Muhammad, Jawad Ishfaq and Naeem ullah Khan(2015). Bank Profitability, Inflation and Cost Efficiency-A Case of Pakistani Banks. International Journal of Business and Management Review Vol.3, No.1, pp.41-53.

lxxi. Munyambonera, Ezra Francis (2012): Determinants of Commercial Bank Performance in Sub-Saharan Africa. Faculty of Economics and Management Makerere University.

lxxii. Munyambonera, Ezra Francis (2013): Determinants of Commercial Bank Profitability in Sub-Saharan Africa, International Journal of Economics and Finance; Vol. 5, No. 9

lxxiii. Naser Hooshyari and Abdollah Pakdel Moghanloo (2015). Evaluating the impact of Inflation on profitability of banks. Kuwait Chapter of Arabian Journal of Business and Management Review Vol. 4, No.9.

lxxiv. Nawaf Ahmad Salem AlGhusin (2015). The Impact of Financial Leverage, Growth, and Size on Profitability of Jordanian Industrial Listed Companies. Research Journal of Finance and Accounting. 
lxxv. Ndifon Ojong Ejoh and Ubana Ubi Iwara(2014). The Impact of Capital Adequacy on Deposit Money Banks' Profitability in Nigeria. Research Journal of Finance and Accounting. Vol.5, No.12.

lxxvi. Okafor Chinonye, lkechukwu Kelikume and Umoren Adebimpe (2010). The Effect of Capital Adequacy on Banks' Performance: Evidencefrom Nigeria. Journal of Business Research, Fourth Edition, VOL. 4, Nos. 1 \& 2

lxxvii. Olaoye Festus Oladipupo and Olarewaju Odunayo M (2015): Determinants Of Deposit Money Banks' Profitability In Nigeria. Kuwait Chapter of Arabian Journal of Business and Management Review Vol. 4, No.9.

lxxviii. Olawale Femi Kayode, Tomola Marshal Obamuyi, James Ayodele Owoputi and Felix Ademola Adeyefa (2015):Credit Risk and Bank Performance in Nigeria. IOSR Journal of Economics and Finance Volume 6, Issue 2. Ver. II.

lxxix. Oleka D. Chioma, Eyisi S.Adanma and Onyeze N. Clementina (2014).Empirical Study of the Impact of Inflation on Bank Performance: Implication for Investment Decision Making in Banking Industry in Nigeria. Humanity \& Social Sciences Journal 9 (2).

lxxx. Olubisi, Friday Oluduro (2015): Academia Arena 2015;7(1) http:/ / www.sciencepub.net/ academia.

lxxxi. Onaolapo A.A. and Adebayo, E.O. (2012). Effect of Capital Adequacy on the Profitability of Nigerian Banking Sector. Journal of Money, Investment and Banking. Issue 24.

lxxxii. Paolo, Saona Hoffmann (2011). Determinants of the Profitability of the US Banking Industry. International Journal of Business and Social Science Vol. 2 No. 22.

lxxxiii. Perry, P. (1992). Do Banks Gain or Lose From Inflation. Journal of Retail Banking, 14(2), 25-30. (2007-2011). International Journal of Academic Research in Accounting, Finance and Management Sciences Vol. 3, No. 4.

lxxxiv. Profitability among Commercial Banks in Namibia. Global Advanced Research Journal of Management and Business Studies. Global Advanced Research Journals. Vol. 4(6)

lxxxv. Ryan Stever (2007). Bank size, credit and the sources of bank market risk. Bank for

lxxxvi. Samina Riaz (2013): Profitability Determinants of Deposit Money Banks in Paksitan- Proceedings of 6th International Business and Social Sciences Research Conference.

lxxxvii. Samuel Alemu (2015). Masters of Science (Accounting and Finance) Thesis. Addis Ababa University, Addis Ababa, Ethiopian.

lxxxviii. Samuel Hymore Boahene, Julius Dasah and Samuel Kwaku Agyei (2012). Credit Risk and Profitability of Selected Banks in Ghana. Research Journal of Finance and Accounting. Vol 3, No 7.

lxxxix. Sarawan Angklomkliew, Jason George and Frank Packer (2009). Issues and developments in loan loss provisioning: the case of Asia. BIS Quarterly Review.

xc. Sayilgan G, Yildirim O (2009). Determinants of Profitability in Turkish Banking Sector: 2002-2007, International Research Journal of Finance and Economics, No 28, pp 207-214.

xci. School of Economics, Ukraine.

xcii. Shehu Usman Hassan and Abubakar Ahmed (2012). Ownership Structure And Oppurtunistic Accounting: A Case Of Listed Food And Beverage Firms In Nigeria. International Journal of Physical and Social Sciences. Volume 2, Issue 7

xciii. Shehu Usman Hassan and Musa Adeiza Farouk (2014). Firm Attributes and Earnings Quality of listed Oil and Gas Companies in Nigeria. Research Journal of Finance and Accounting. Vol.5, No.17

xciv. Stephen Oluwafemi Adeusi, Funso Tajudeen Kolapo and Adewale Olufemi Aluko (2014). Determinants Of Commercial Banks' Profitability Panel Evidence From Nigeria. International Journal of Economics, Commerce and Management United Kingdom Vol. II, Issue 12.

xcv. Tamim Mahamud Foisal, Anamul Haque and Ashraful Alam (2016). Determinants of Profitability- A Case from the State-owned Commercial Banks of Bangladesh. European Journal of Business and Management.Vol.8, No.10.

xcvi. Tesu Ramona (2013). BASEL I, II, III: Challenges to the Bank's Capital Adequacy. JEL Classifications: G21 2nd Issue.

xcvii. Tuzcu SE (2015). The Effect of Derivatives Activity on Bank Profitability Before and During The Subprime Mortgage Crisis: Evidence From Turkey', Ankara Üniversitesi Sosyal Bilimler Dergisi.

xcviii. Valentina Flamini, Calvin MCDonald and Liliana Schumacher (2009):The Determinants of Commercial Bank Profitability in Sub-Saharan Africa. IMF Working Paper.

xcix. William Bentum (2012). The Determinants of Profitability of the Commercial Banks in Ghana during the Recent Years of Global Financial Crisis. Master Thesis. Aarhus School of Business

c. Xuezhi Qin and Dickson Pastory (2012). Commercial Banks Profitability Position: The Case of Tanzania. International Journal of Business and Management; Vol. 7, No. 13

ci. Yong Tan \& Christos Floros(2012). Bank profitability and GDP growth in China: A Note. Journal of Chinese Economic and Business Studies Volume 10, Issue 3.

cii. http:/ / www.ghanaweb.com/ GhanaHomePage/ economy/ gse.php

ciii. http:/ / www.annualreportsghana.com/ Services/ Reports.aspx

civ. http:/ / www.moneyhub.net/ scripts/ cgiip.wsc/globalone/ htm/ company_list.r?picountry-id=525\&pcsort=Alphabetic

cv. http:/ / www.nigerianstockexchange.com/ Issuers-section/ listed-securities

cvi. https:/ / www.ing.com/ About-us/ Profile-Fast-facts/ The-role-of-banks/ Five-things-to-know-about-the-size-ofbanks.htm. 


\section{Appendix}

List of Quoted Banks

Listed Banks on the Ghana Stock Exchange

As At 31st December, 2015

- CAL Bank Limited

- Ecobank Ghana Limited

- Ecobank Transnational Incorporated

- Ghana Commercial Bank Limited

- HFC Bank (Ghana)

- Societe Generale Ghana Limited

- Standard Chartered Bank Ghana Limited

- Trust Bank (Gambia) Limited

Listed Banks on the Nigerian Stock Exchange

As At 31st December, 2015

- Access Bank Plc.

- Diamond Bank Plc

- Ecobank Transnational Incorporated

- First Bank Of Nigeria (Fbn) Holdings Plc

- FCMB Group Plc.

- Fidelity Bank Plc

- Guaranty Trust Bank Plc.

- Skye Bank Plc

- Stanbic Ibtc Holdings Plc

- Sterling Bank Plc.

- Union Bank Nig.Plc

- United Bank For Africa Plc

- Unity Bank Plc

- Wema Bank Plc.

- Zenith International Bank Plc

Sampled Listed Banks in Nigeria

- Access Bank plc.

- Diamond Bank plc.

- First City Monument Bank plc.

- Fidelity Bank plc.

- First Bank plc.

- GTB plc.

- Skye bank plc.

- Stanbic ibtc bank plc.

- Sterling bank plc.

- UBA plc.

- Union bank plc.

- Unity bank plc.

- Wema bank plc.

- Zenith bank plc.

Sampled Listed Banks in Ghana

- Cal bank

- Ecobank

- Ecobank Transnational Inc

- Ghana Commercial Bank

- HFC Bank Ghana

- Societe General Ghana

- Standard Chartered Bank Ghana 


\begin{tabular}{|r|rrrrr|}
\hline Variable & Obs & Mean & Std. Dev. & Min & Max \\
\hline roa & 167 & .0168263 & .0387623 & -.3 & .1 \\
eqta & 167 & .1398802 & .0684333 & -.23 & .31 \\
liptl & 167 & .0477246 & .1075504 & 0 & 1.08 \\
size & 167 & 8.155389 & 1.19504 & 5.23 & 10.18 \\
inf & 168 & 11.74583 & 3.023557 & 8 & 19.2 \\
& & & & & \\
\hline
\end{tabular}

Table 6: Results of a Cross-Country and a Single-Country

Summary Statistic (Nigeria and Ghana) Author's Compilation (2016)

\begin{tabular}{|r|ccccc|}
\hline \multicolumn{6}{|c|}{ Skewness/Kurtosis tests for Normality } \\
\cline { 2 - 5 } Variable & Obs & Pr(Skewness) & Pr(Kurtosis) & adj chi2(2) & Prob>chi2 \\
& & & & & \\
\hline rod & 167 & 0.0000 & 0.0000 &. & 0.0000 \\
eqta & 167 & 0.0000 & 0.0000 & 60.85 & 0.0000 \\
IIptl & 167 & 0.0000 & 0.0000 &. & 0.0000 \\
size & 167 & 0.0464 & 0.0012 & 12.32 & 0.0021 \\
inf & 168 & 0.0001 & 0.9162 & 12.71 & 0.0017 \\
\hline
\end{tabular}

Table 7: Strata Output

Correlation Matrix (Nigeria and Ghana)

Normality Test (Nigeria and Ghana) 


\begin{tabular}{|c|c|c|c|c|c|c|}
\hline & & ROA & EQTA & LLPTL & SIZE & INF \\
\hline \multirow{6}{*}{$\begin{array}{c}\text { Pearson } \\
\text { Correlation }\end{array}$} & $\mathrm{ROA}$ & 1.000 & .437 & -.670 & -.095 & .077 \\
\hline & EQTA & .437 & 1.000 & -.451 & .006 & .009 \\
\hline & $\begin{array}{c}\text { LLPT } \\
\text { L }\end{array}$ & -.670 & -.451 & 1.000 & -.072 & .049 \\
\hline & SIZE & -.095 & .006 & -.072 & 1.000 & -.402 \\
\hline & INF & .077 & .009 & .049 & -.402 & 1.000 \\
\hline & ROA & EQTA & LLPTL & SIZE & INF & \\
\hline \multirow[t]{5}{*}{ Sig. (1-tailed) } & $\mathrm{ROA}$ & & .000 & .000 & .110 & .160 \\
\hline & EQTA & .000 & & .000 & .469 & .455 \\
\hline & $\begin{array}{c}\text { LLPT } \\
\text { L }\end{array}$ & .000 & .000 & . & .178 & .263 \\
\hline & SIZE & .110 & .469 & .178 & & .000 \\
\hline & INF & .160 & .455 & .263 & .000 & \\
\hline \multirow[t]{5}{*}{$\mathrm{N}$} & ROA & 167 & 167 & 167 & 167 & 167 \\
\hline & EQTA & 167 & 167 & 167 & 167 & 167 \\
\hline & $\begin{array}{c}\text { LLPT } \\
\text { L }\end{array}$ & 167 & 167 & 167 & 167 & 167 \\
\hline & SIZE & 167 & 167 & 167 & 167 & 167 \\
\hline & INF & 167 & 167 & 167 & 167 & 167 \\
\hline
\end{tabular}

Table 8: SPSS Output

Test for Heteroskedasiticity (Nigeria and Ghana)

Breusch-Pagan / Cook-heisberg test for heteroskedasticity

Ho: Constant variance

Variables: fitted values of roa

chi2(1) $=329.65$

Prob $>$ chi2 $=0.0000$

Table 9: SPSS Output

Test for Multicollinearity (Variance Inflation Factor)

(Nigeria and Ghana) 


\begin{tabular}{|r|cr|}
\hline \multirow{2}{*}{ Variable } & VIF & $1 /$ VIF \\
\hline llptl & 1.26 & 0.790923 \\
eqta & 1.26 & 0.795295 \\
size & 1.20 & 0.835676 \\
inf & 1.19 & 0.837685 \\
\hline Mean VIF & 1.23 & \\
\hline
\end{tabular}

Table 10: SPSS Output

Wooldridge Test for Autocorrelation in Panel Data (Nigeria and Ghana)

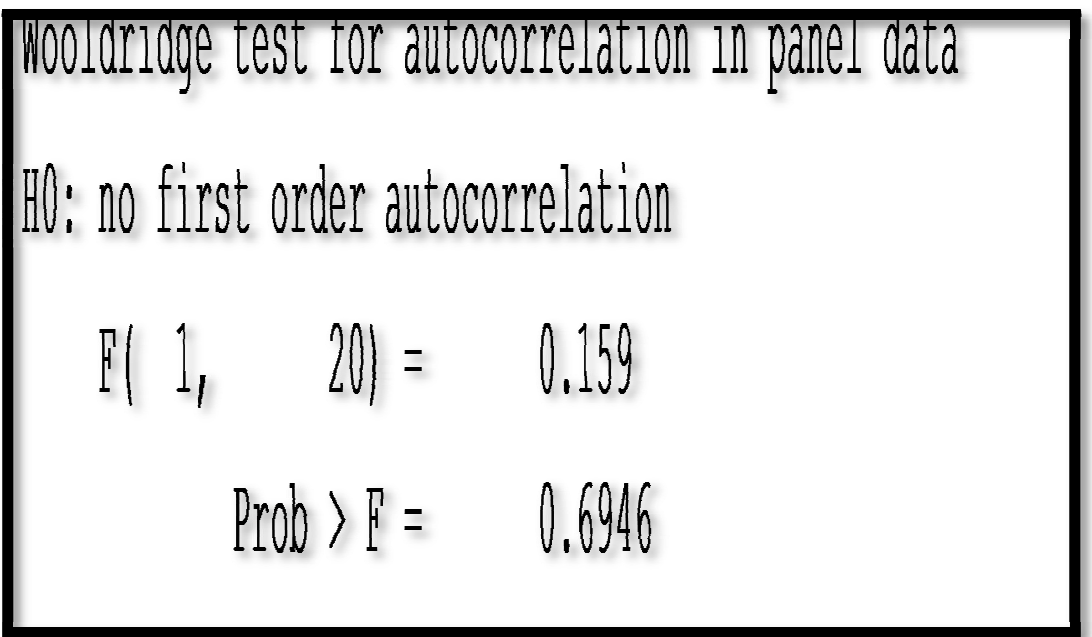

Table 11: Stata Output

- tsset index year

panel variable: index (strongly balanced)

time variable: year, 2008 to 2015

$$
\text { delta: } 1 \text { unit }
$$

Table 12: Stata Output

Fixed Effect Estimation with Vce Robust Option (Nigeria and Ghana) 


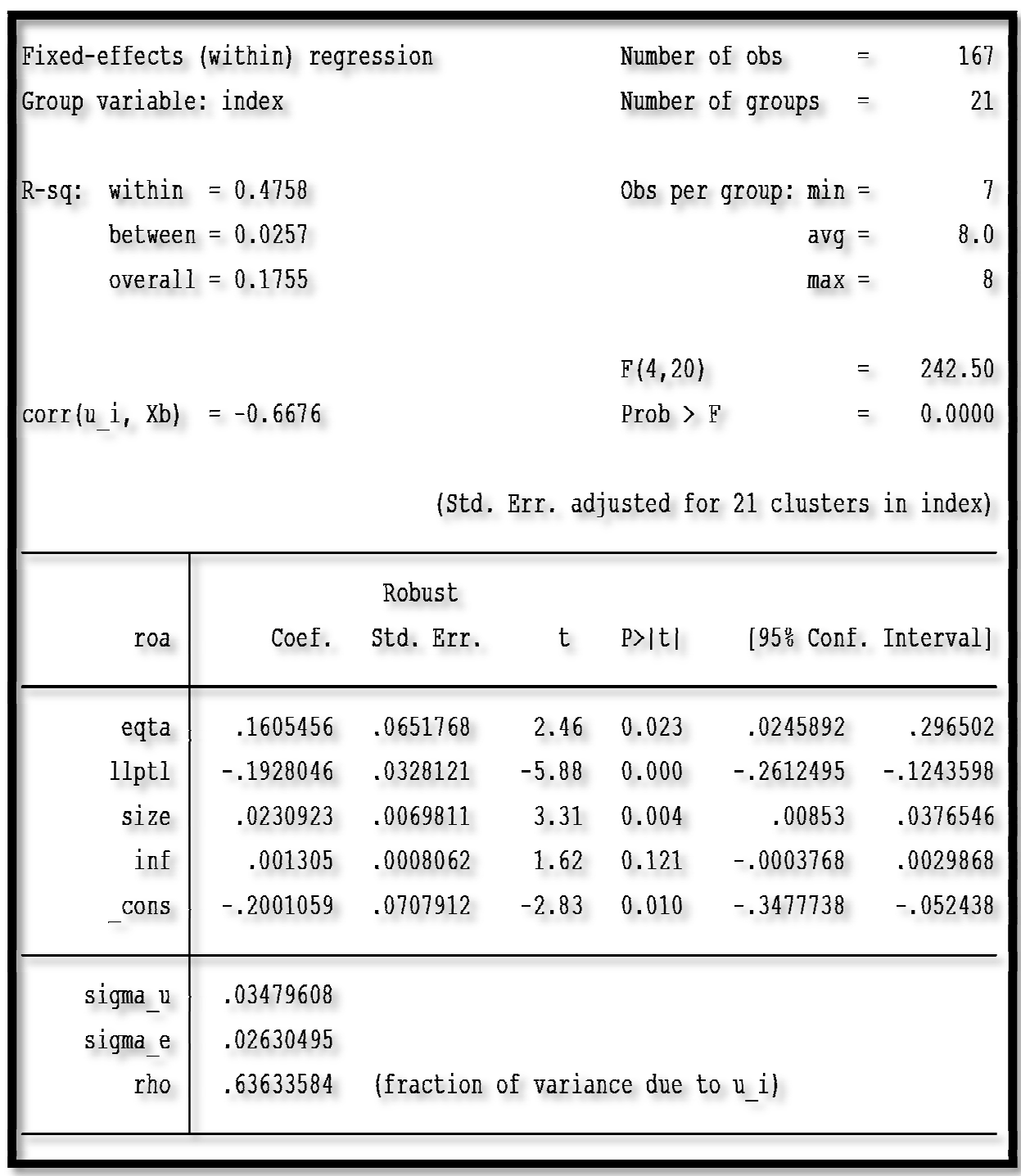

Table 13: Stata Output

Random Effect (Nigeria and Ghana) 


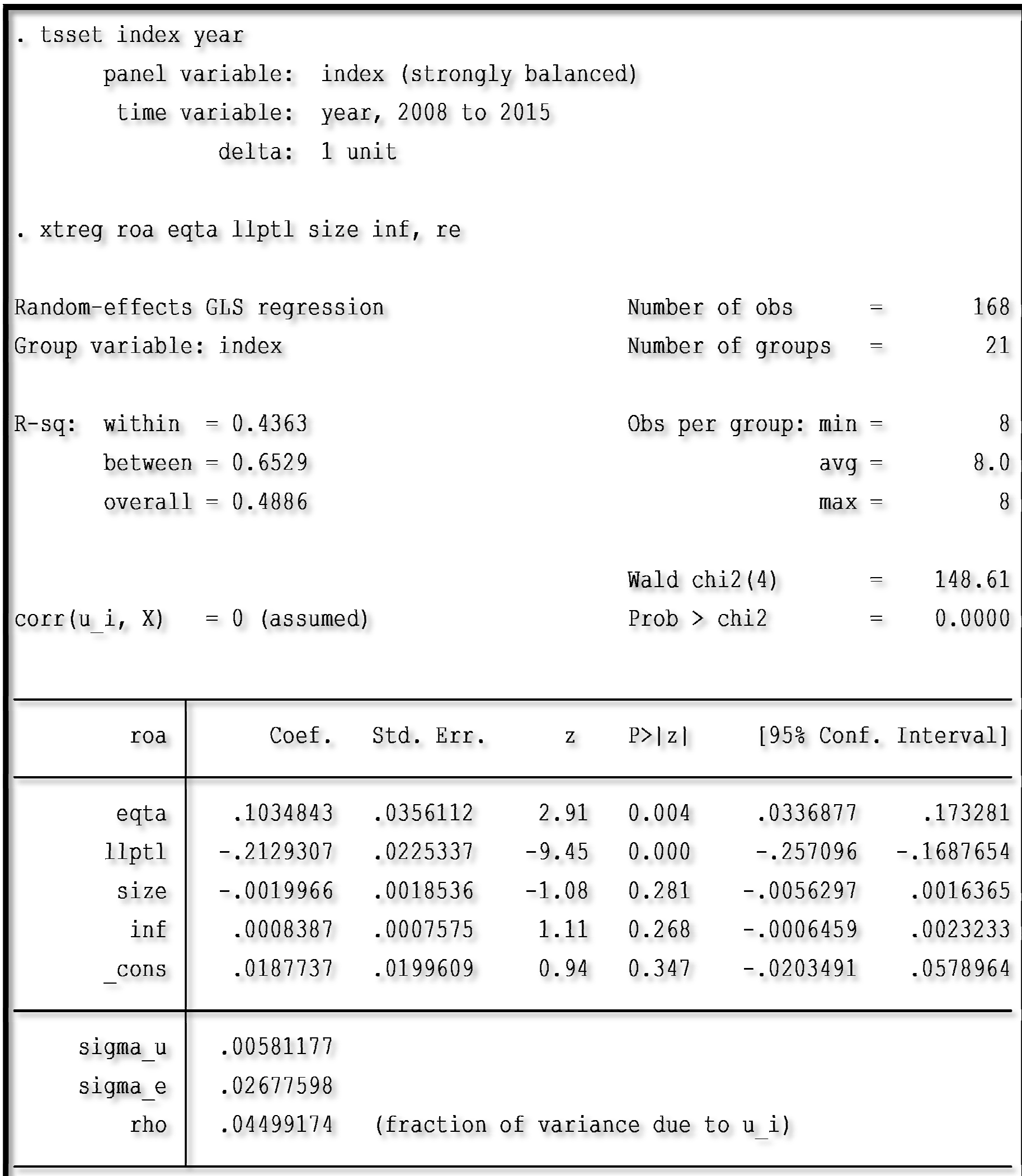

Table 14 


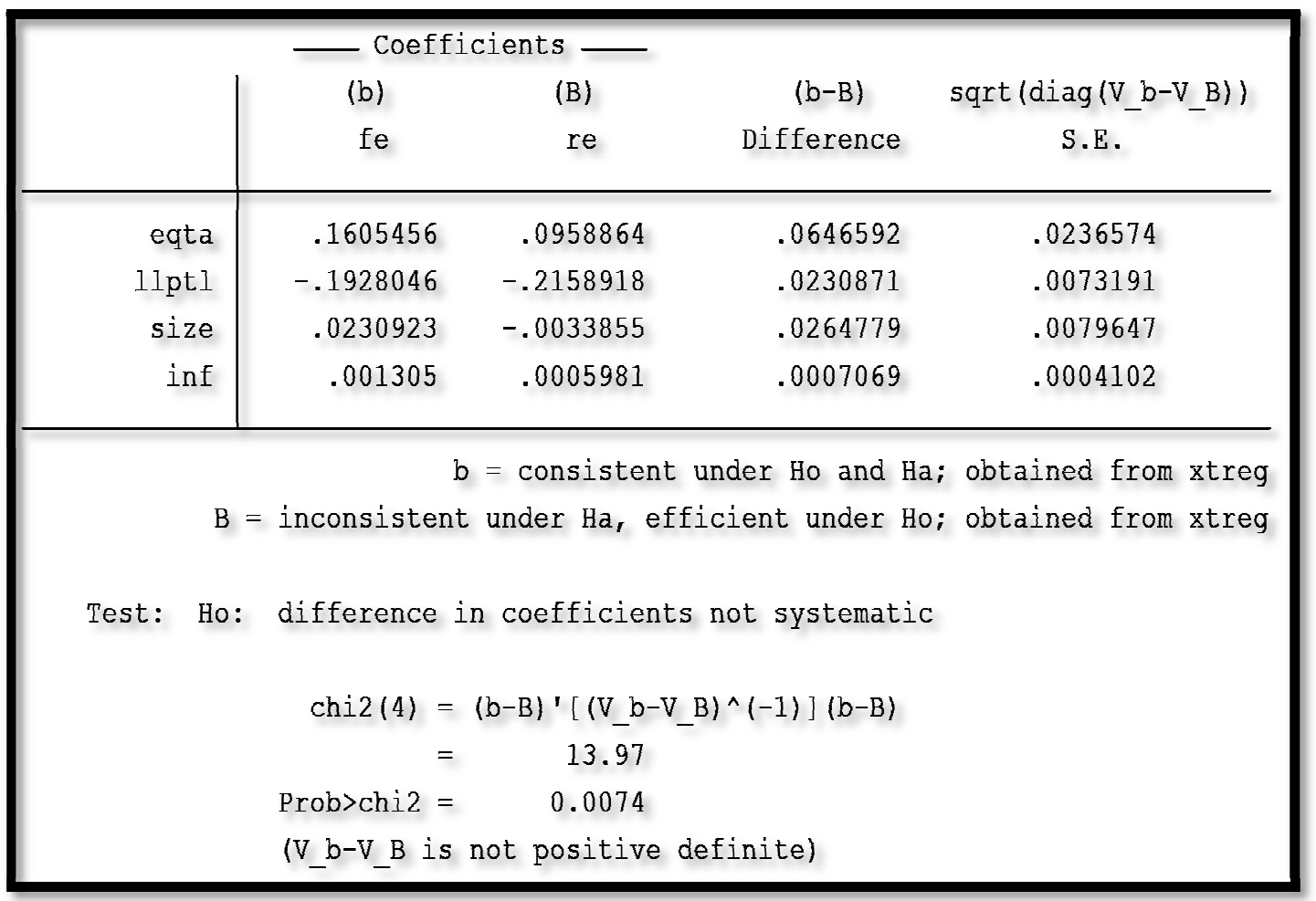

Table15: Hausman Test (Nigeria and Ghana)

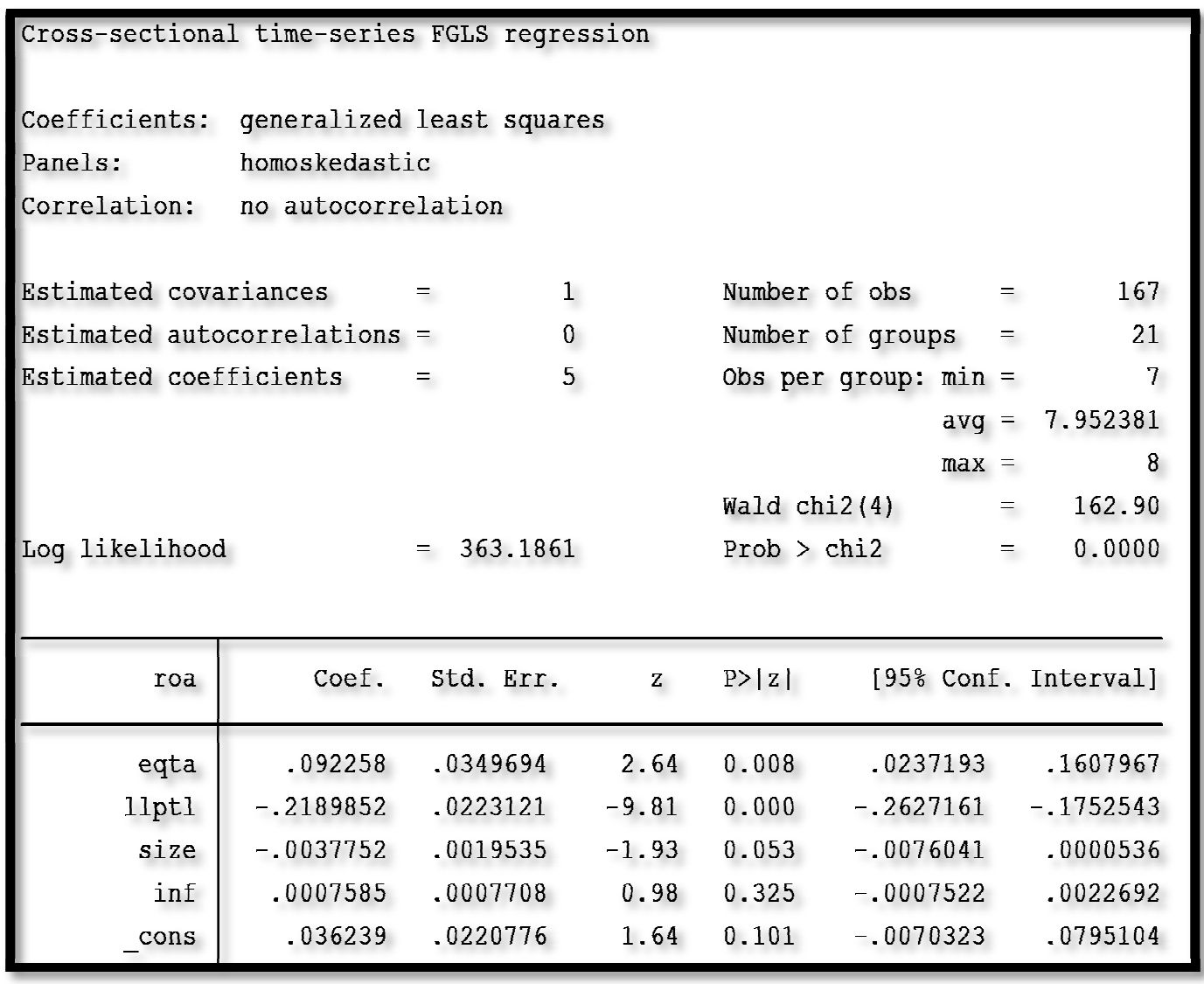

Table16: STATA Output

Feasible Generalized Least Square (FGLS) (Nigeria and Ghana) 


\begin{tabular}{|r|rrrrr|}
\hline Variable & Obs & Mean & Std. Dev. & Min & Max \\
\hline roa & 112 & .0086607 & .0432986 & -.3 & .1 \\
eqta & 112 & .14 & .0816497 & -.23 & .31 \\
llptl & 112 & .0580357 & .1290146 & 0 & 1.08 \\
size & 112 & 8.617054 & 1.124744 & 0 & 10.18 \\
inf & 112 & 10.7875 & 1.953888 & 8 & 13.7 \\
& & & & & \\
\hline
\end{tabular}

Table 17: Regression Results- Nigeria Descriptive Statistics

\begin{tabular}{|r|ccccc|}
\hline Variable & Obs & $W$ & $V$ & $z$ & Prob \\
\hline roa & 112 & 0.60956 & 35.447 & 7.964 & 0.000 \\
eqta & 112 & 0.87268 & 11.559 & 5.463 & 0.000 \\
llptl & 112 & 0.39768 & 54.684 & 8.932 & 0.000 \\
size & 112 & 0.71091 & 26.246 & 7.293 & 0.000 \\
inf & 112 & 0.94725 & 4.789 & 3.496 & 0.000 \\
& & & & & \\
\hline
\end{tabular}

Table 18: Normality Test Correlation Matrix 


\begin{tabular}{|r|rrrrr|}
\hline & rod & eqta & llptl & size & inf \\
\hline rod & 1.0000 & & & & \\
eqta & 0.4768 & 1.0000 & & & \\
liptl & -0.6893 & -0.4693 & 1.0000 & & \\
size & 0.1907 & 0.1893 & -0.1833 & 1.0000 & \\
inf & -0.0573 & 0.0723 & 0.1742 & -0.1296 & 1.0000 \\
\hline
\end{tabular}

Table 19:

Breusch-Pagan / Cook-reisberg test for heteroskedasticity

Ho: Constant variance

Variables: fitted values of roa

$\operatorname{chi2}(1)=255.81$

Prob $>$ chi2 $=0.0000$

Table 20: Test for Heteroskedasticity

\begin{tabular}{r|cr|}
\hline & & \\
Variable & VIF & $1 / V I F$ \\
\hline IlptI & 1.37 & 0.731834 \\
eqta & 1.35 & 0.740580 \\
inf & 1.08 & 0.924591 \\
size & 1.07 & 0.937872 \\
\hline Mean VIF & 1.22 & \\
\hline
\end{tabular}

Table 21: Test for Multicollinearity 


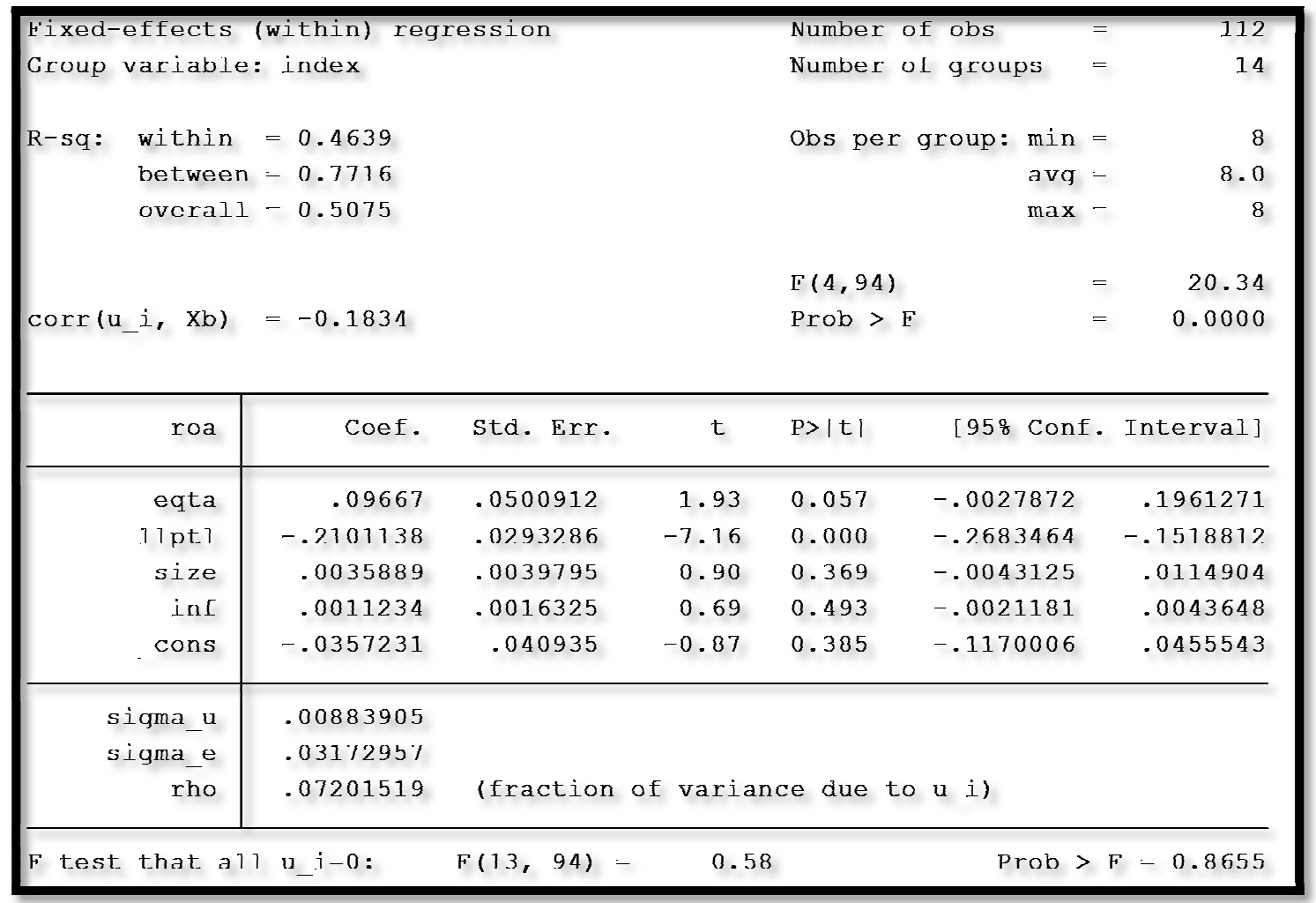

Table 22: Fixed Effect Model

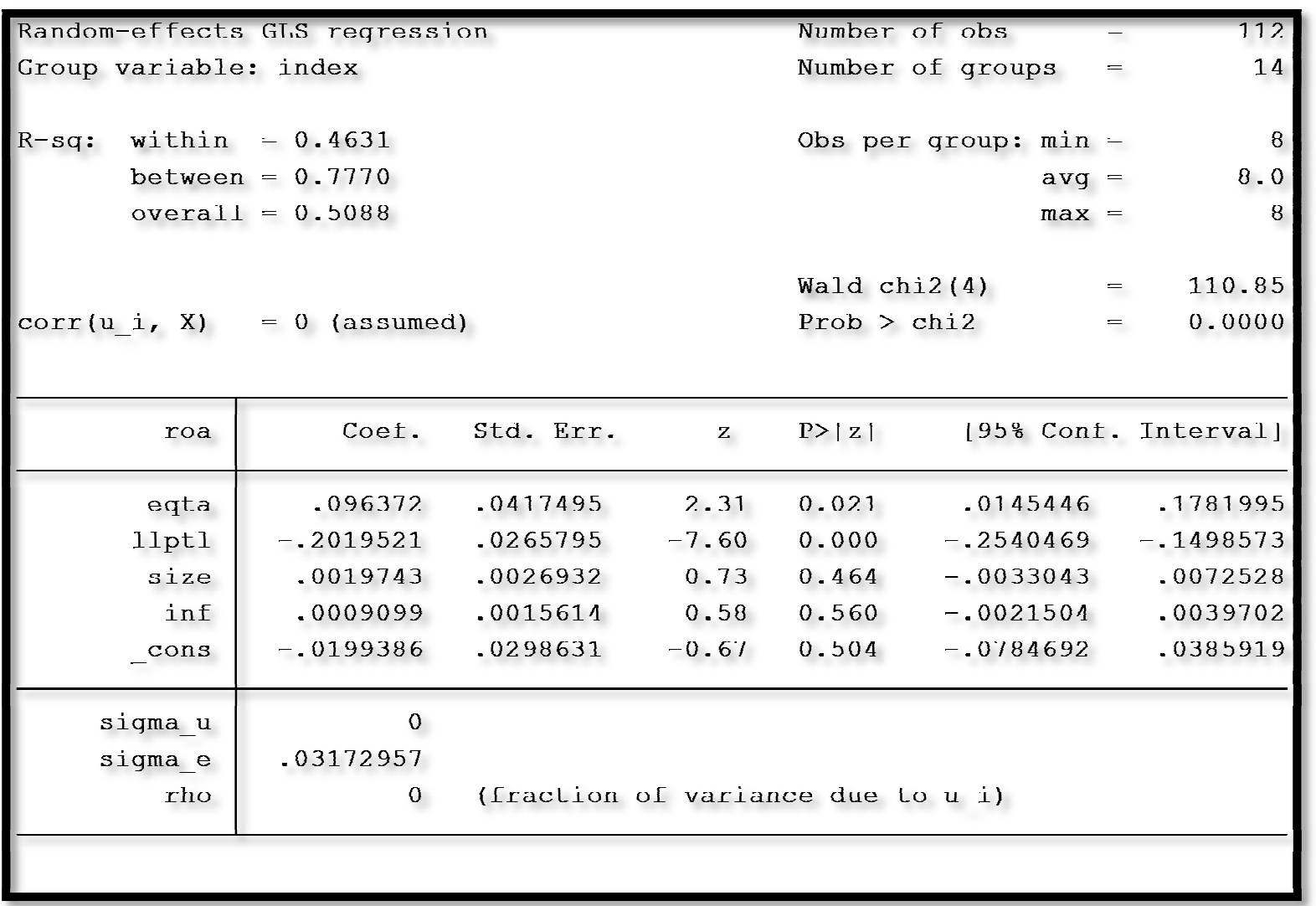

Table 23: Random Effect Model 


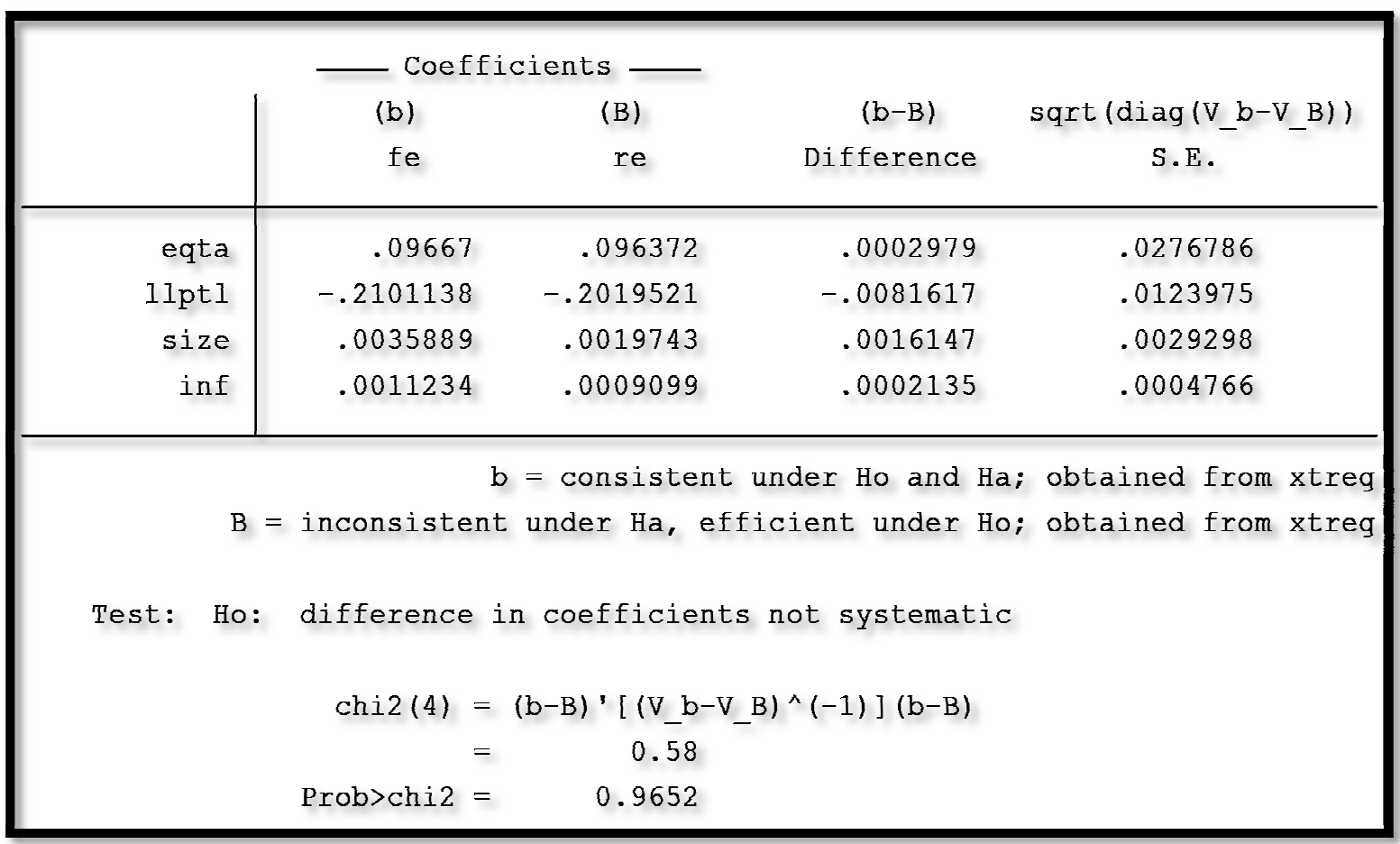

Table 24: Hausman Specification Test

\begin{tabular}{|r|rrrrr|}
\hline Variable & Obs & Mean & Std. Dev. & Min & Max \\
\hline roa & 56 & .0329488 & .0186604 & -.0227047 & .0696098 \\
eqta & 56 & .1371433 & .0322723 & .0724444 & .2233533 \\
liptl & 56 & .0262817 & .0262958 & .0026325 & .174488 \\
size & 56 & 7.086812 & 1.170065 & 5.228437 & 10.09591 \\
inf & 56 & 13.6625 & 3.800362 & 8.7 & 19.2 \\
\hline
\end{tabular}

Table 25: Regression Result- Ghana Descriptive Statistics 


\section{Shapiro-Wilk W test for normal data}

\begin{tabular}{r|rcrcc} 
Variable & Obs & W & V & Z & Prob $>$ Z \\
\hline roa & 56 & 0.98166 & 0.944 & -0.124 & 0.54947 \\
eqta & 56 & 0.98721 & 0.658 & -0.899 & 0.81558 \\
llptl & 56 & 0.60983 & 20.072 & 6.439 & 0.00000 \\
size & 56 & 0.89364 & 5.472 & 3.649 & 0.00013 \\
inf & 56 & 0.91970 & 4.131 & 3.045 & 0.00116 \\
\hline
\end{tabular}

Table 26: Normality Test

\begin{tabular}{|r|rrrrr|}
\hline & rod & eqta & llptl & size & inf \\
\hline rod & 1.0000 & & & & \\
eqta & 0.3411 & 1.0000 & & & \\
1lptl & -0.2605 & 0.0566 & 1.0000 & & \\
size & -0.2081 & -0.4218 & -0.0236 & 1.0000 & \\
inf & -0.1456 & -0.0462 & 0.2540 & -0.0932 & 1.0000 \\
\hline
\end{tabular}

Table 27: Correlation Matrix

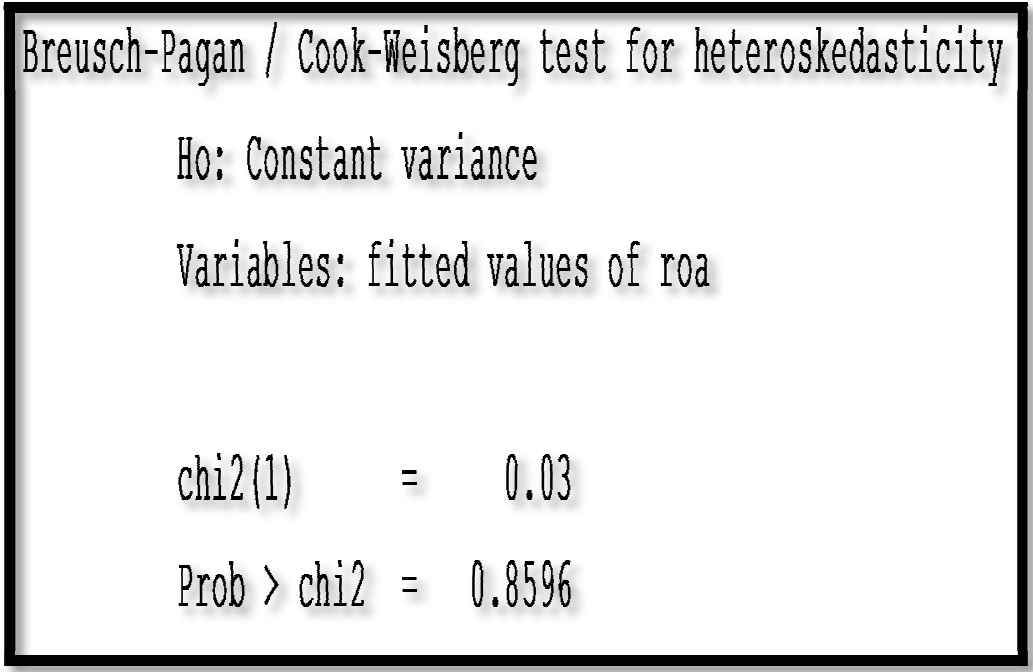

Table 28: Test for Heteroskedasticity 


\begin{tabular}{|r|cr|}
\hline Variable & VIF & $1 /$ VIF \\
\hline size & 1.24 & 0.808465 \\
eqta & 1.23 & 0.809739 \\
inf & 1.09 & 0.916349 \\
Ilptl & 1.08 & 0.929758 \\
\hline Mean VIF & 1.16 & \\
\hline
\end{tabular}

Table 29: Test for Multicollinearity

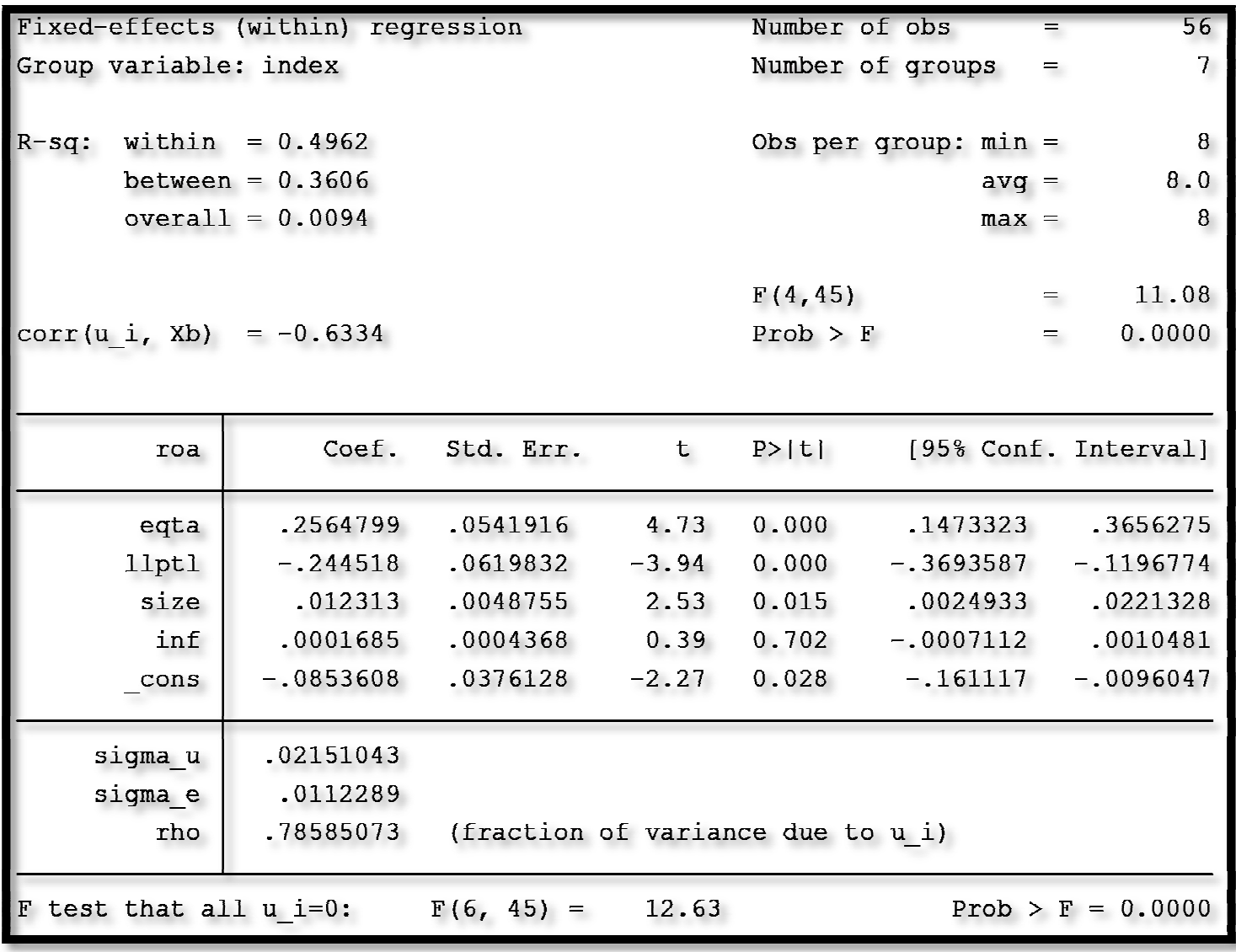

Table 30: Fixed Effect Model 


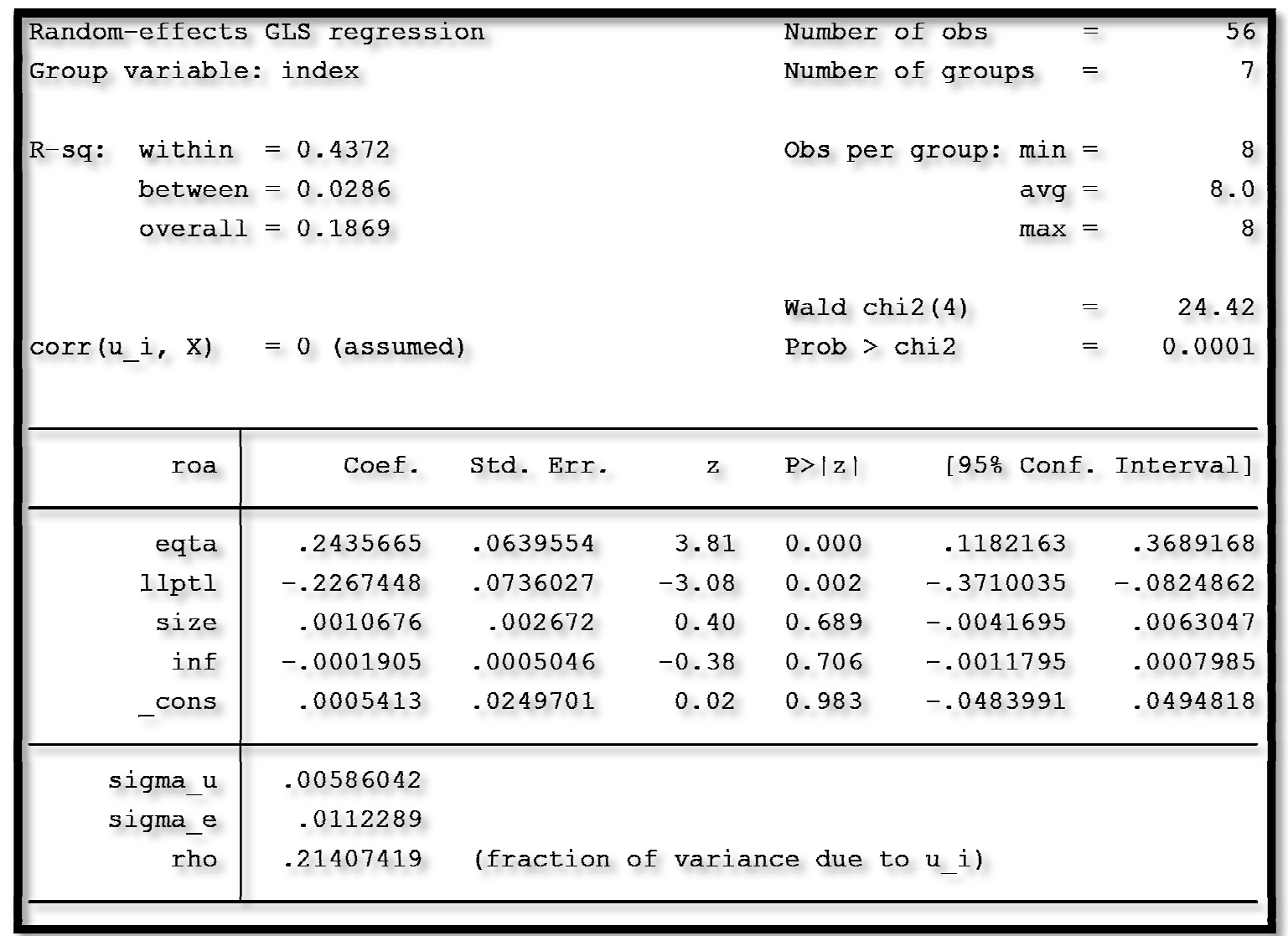

Table 31: Random Effect Model

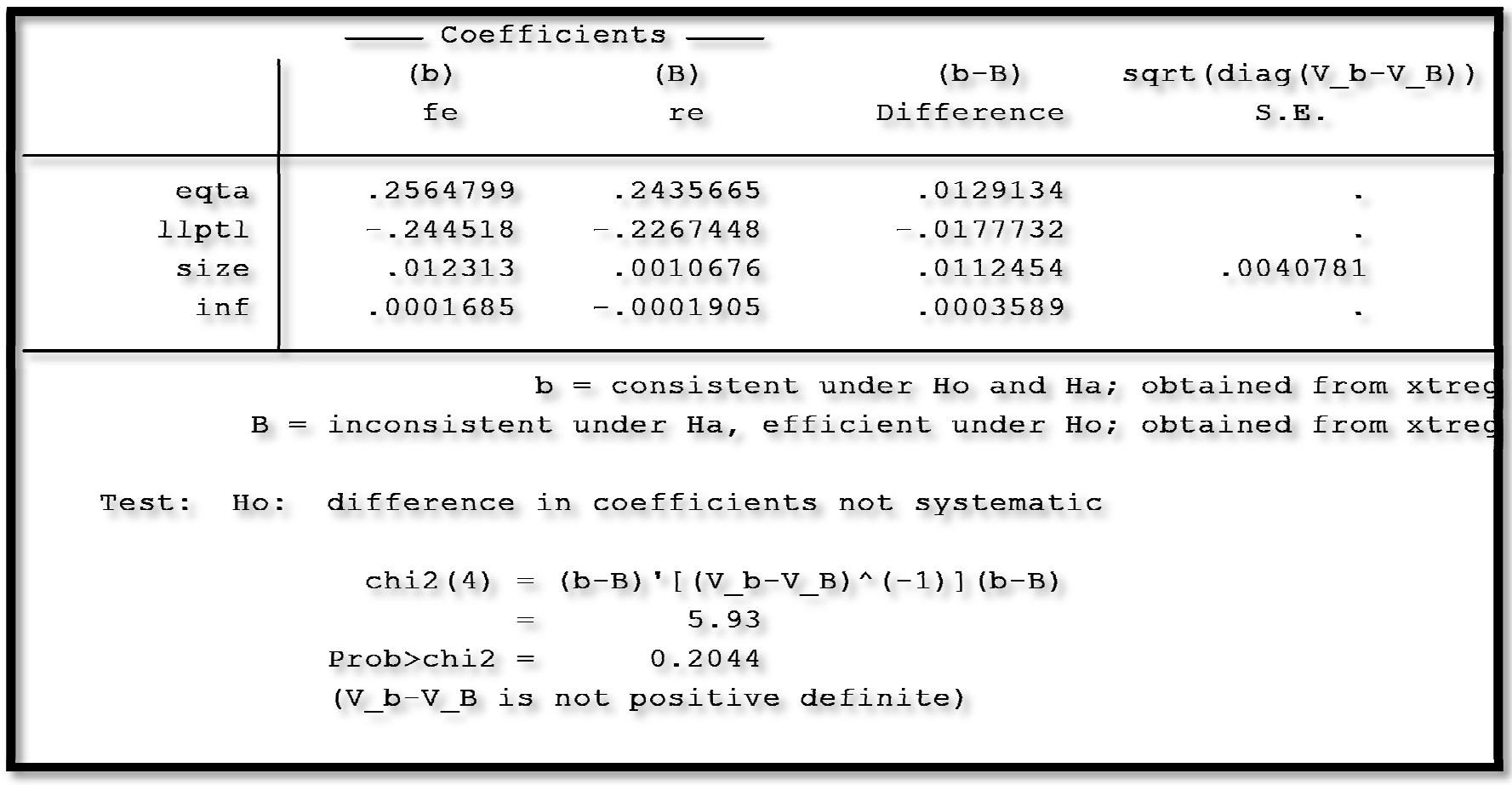

Table 32: Hausman Specification Test 